\title{
Application, Chemical Interaction and Fate of Iron Minerals in Polluted Sediment and Soils
}

\author{
Bjorn P. von der Heyden ${ }^{1}$ - Alakendra N. Roychoudhury ${ }^{1}$
}

Published online: 16 October 2015

(C) Springer International Publishing AG 2015

\begin{abstract}
Due to the high surface reactivity and redox chemistry, iron $(\mathrm{Fe})$ minerals have a strong control on contaminant speciation, mobility and degradation. This has been well established for sediment and solution systems, and this review evaluates the role of $\mathrm{Fe}$ minerals in contaminant cycling from a sediment pollution perspective. Sediment redox conditions govern the Fe mineralogy, and a detailed description is given for Fe mineral interactions with contaminants in both oxic and sub/anoxic sediment horizons. These interactions include contaminant immobilisation through adsorption and coprecipitation mechanisms and contaminant degradation and speciation changes caused by Fe redox chemistry. Based on these reductive and adsorptive capabilities, recent advances in Fe amendment technologies, particularly in the field of engineered zero-valent Fe nanoparticles, have shown promising results for the treatment of polluted soils and sediments. However, the variable chemical and physical dynamics of sediment systems remains a limitation to the global application of these technologies.
\end{abstract}

Keywords Sediment pollution · Soil pollution · Iron · Iron minerals $\cdot$ Mineral amendments $\cdot$ Sediment remediation . Coupled redox transformation $\cdot$ Iron nanoparticles $\cdot \mathrm{Fe}(0)$

This article is part of the Topical Collection on Sediment and Other Pollutions

Alakendra N. Roychoudhury

roy@sun.ac.za

1 Department of Earth Sciences, Stellenbosch University, Stellenbosch 7600, South Africa

\section{Introduction}

Rampant anthropogenic activity has detrimentally increased the pollution levels in all of the earth's natural reservoirs [e.g. 1, 2]. Because sediments represent a sink for these pollutants, sediment pollution in marine, estuarine, lacustrine and fluvial systems is increasingly being recognised as an emerging global concern [3-5]. Accumulation of toxic metals, metalloids and persistent organic contaminants in aquatic sediments poses a threat to benthic organisms and can further impact on other aquatic organisms if contaminants are released into the aqueous phase either through sediment re-suspension events (both natural (e.g. slumping, bioturbation) and induced (e.g. dredging activity)) or through chemical variability in the sediment environment (e.g. redox changes, $\mathrm{pH}$ changes). Trace metals are particularly important in this regard, as their persistence, toxicology and propensity to bio-accumulate in higher trophic levels are concerning for public health [e.g. 6, 7].

Iron is the most abundant transition metal in the Earth's crust, yet it is not commonly reported as a soil or sediment pollutant $[8,9]$. An exception lies in the rice industry, where low oxygen conditions enhance Fe(II) concentrations and can result in Fe toxicity, which detrimentally affects rice yields $[10,11]$. Under oxic conditions, however, the bioavailability and toxicity of iron is limited by its exceedingly low solubility [12] which results in the precipitation and subsequent stability of iron (oxy-hydr)oxide minerals (e.g. ferrihydrite, goethite, hematite). These ubiquitous mineral phases are redox reactive and are well known for their propensity for adsorbing various inorganic and organic pollutants [e.g. 13-17]. They have thus attracted much attention as a viable mineral amendment option and have successfully been applied to remediation of polluted soils [see reviews 18-20] and sediments [21-23]. 
Typically, these amendments can be applied as in situ soil treatments whereas sediment treatments require either prior dredging [24] or the development of a confined aquatic disposal cell [25]. Qian and co-workers [23] have shown that in situ ferrihydrite additions are able to immobilise various trace metal contaminants in sediments whilst simultaneously decreasing their bioavailability and toxicity. Hematite and zero-valent iron additions have also been shown to reduce trace metal toxicity in sediments [26] and pilot-scale work on dredged sediment samples has shown that these mineral phases have significant ability to immobilise $\mathrm{As}, \mathrm{Cd}, \mathrm{Cu}, \mathrm{Mo}$, $\mathrm{Ni}$ and $\mathrm{Zn}$ when applied at a $5 \%$ amendment ratio [24].

Because of the importance of $\mathrm{Fe}$ and $\mathrm{Fe}$ minerals to contaminant cycling and stabilisation, this work assesses the status of knowledge of these interactions in contaminated sediment systems. Although high iron loading can result in $\mathrm{Fe}$ toxicity, these cases are relatively isolated and discussions on $\mathrm{Fe}$ as a pollutant thus fall outside of the scope of this review. The role of iron mineral amendments for remediation of polluted sediments is evaluated, and the recent advances in Fe-based amendment strategies (particularly nano-particulate and zero-valent $\mathrm{Fe}$ amendment strategies) are critically reviewed.

\section{Iron Mineralogy and Cycling in Sediments}

Iron represents the fourth most abundant element and the most abundant transition metal in the earth's continental crust. Much of this iron originates from $\mathrm{Fe}$ (II) bound in the lattice structures of ferro-magnesian silicate minerals (e.g. olivine, pyroxene, biotite and amphiboles) and in magnetite, a mixed-valence Fe oxide. Weathering and oxidation under surface environmental conditions cause the low temperature geo- chemical transformation of these minerals into secondary oxides and clay minerals [e.g. 12]. Under these oxic conditions, ferric iron $(\mathrm{Fe}(\mathrm{III}))$ is the thermodynamically favourable oxidation state and predominantly forms highly insoluble ferric oxide and ferric oxy-hydroxide mineral phases. These can exist either as discreet crystals (including nano particles) or as coatings on other mineral phases, and due to their ubiquity, redox activity and amphoteric surface reactivity, they are known to have a strong control on the chemical properties of soils and sediment.

Depending on the climatic conditions, the most common soil and sediment $\mathrm{Fe}$ (oxy-hydr)oxides are goethite $(\alpha$ $\mathrm{FeOOH})$, hematite $\left(\mathrm{Fe}_{2} \mathrm{O}_{3}\right)$ and amorphous and poorly crystalline phases (including ferrihydrite and green rusts). Lepidocrocite $(\gamma-\mathrm{FeOOH})$ is less common and is typically found in sub-micron scale association with goethite [27], and akaganeite $(\beta-\mathrm{FeOOH})$ is confined to unique chloriderich environments (e.g. acid sulphate wetland sediment [28] and acid mine drainage sediment [29]). The adsorption of contaminants to these $\mathrm{Fe}$ (oxy-hydr)oxides is governed by the ambient $\mathrm{pH}$ conditions and by the reactivity, structure and chemistry of the hydroxyl groups on the mineral surfaces [30]. Contaminant adsorption to Fe mineral surfaces can occur through inner-sphere and outer-sphere complexation reactions, ligand exchange reactions and through the formation of ternary complexes (Eqs. 1-7; after [30]). Spectroscopic investigations have shown that $\mathrm{Fe}$ (oxy-hydr)oxide mineralogy can exert a control of the nature of these bonding interactions, thereby impacting the stability and mobility of the complexed contaminants (Fig. 1). For example, spectroscopic techniques have shown that $\mathrm{Se}(\mathrm{VI})$ forms outer-sphere complex with goethite [32] whereas it coordinates with ferrihydrite via inner-sphere bidentate bonding ([33]; additional examples in [31] and in Fig. 1).

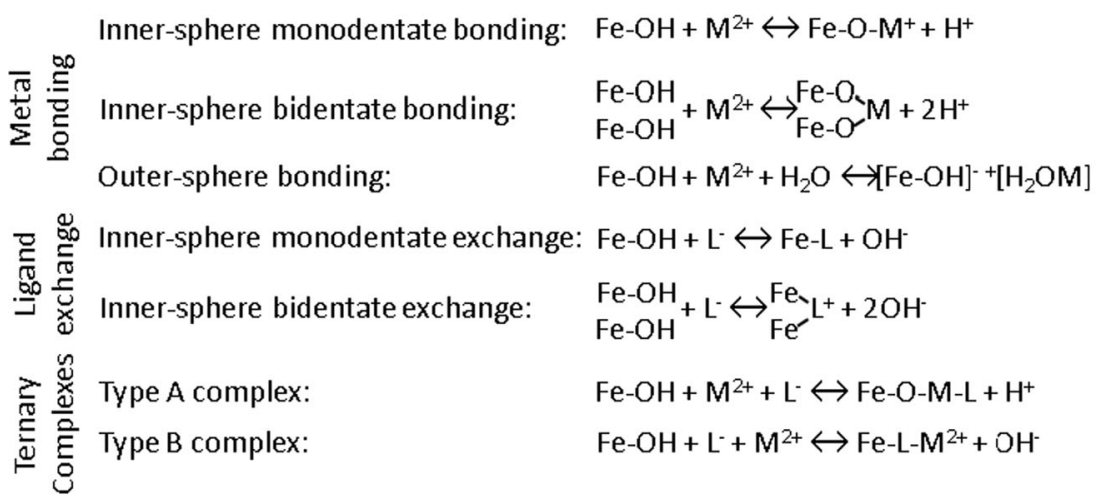

(1)
The iron (oxy-hydr)oxides are stable in the oxic surface layers of the sediment (upper few $\mathrm{mm}$ to $\mathrm{cm}$, depending on sediment grain size distribution); however, as minerals and their associated contaminants are buried and undergo early diagenesis, their stability and speciation change (Fig. 2). Ageing reactions lead to the transformation of amorphous and poorly crystalline phases (e.g. ferrihydrite, schwertmannite) into more crystalline minerals (e.g. goethite, 


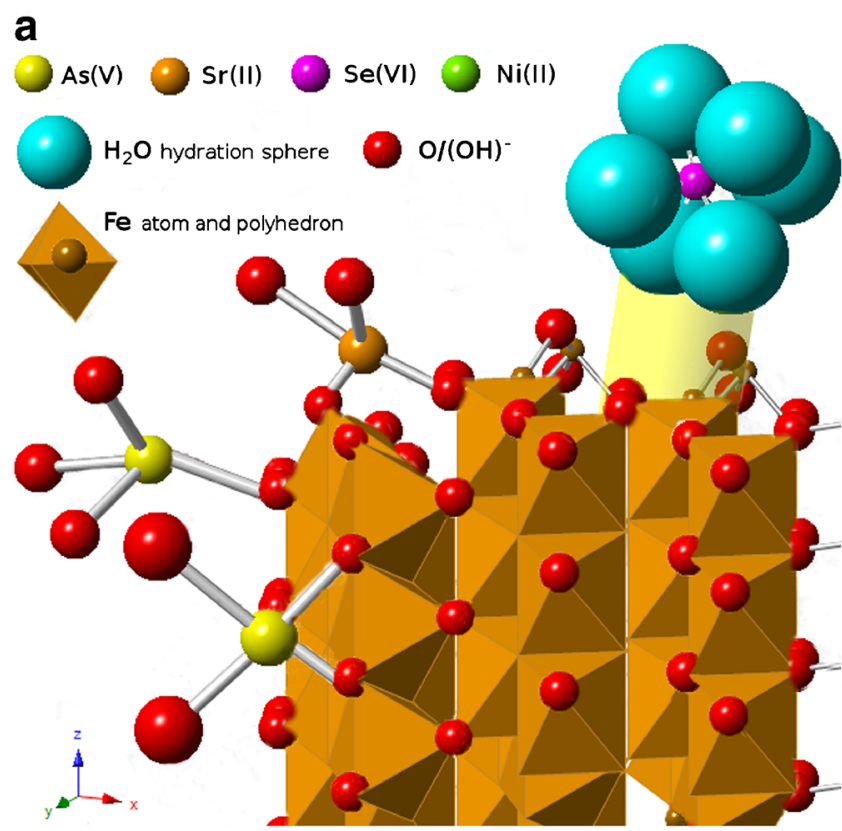

Fig. 1 Comparison between selected bonding interactions at a goethite surface (a) and a ferrihydrite surface (b) highlighting the effect of mineralogical controls on contaminant sorption. Se(VI) forms outersphere complexes with goethite and inner-sphere complexes with ferrihydrite. Sr(II) forms inner-sphere bidentate bonds with goethite but

hematite), whereas reductive biogeochemical reactions (notably organic matter degradation) cause a rapid decrease in the redox potential with depth thereby affecting mineral stability. In the sub-oxic zone, $\mathrm{Fe}(\mathrm{III})$ oxides act as electron acceptors and, following reductive dissolution pathways, Fe(II) and adsorbed and co-precipitated contaminants are released into solution. Mobilised $\mathrm{Fe}(\mathrm{II})_{\mathrm{aq}}$ can migrate to the redox front to further interact with pollutants as a reducing agent. In anoxic sediment, oxygen concentrations are diminished, Fe(III) oxides have largely been reduced and sulphate is an important electron acceptor. Under strongly anoxic (i.e. sulphidic) conditions, sulphide mineral solubility and stability have a strong control on the partitioning of inorganic pollutants between dissolved complexes and solid mineral phases. Iron sulphide minerals include mackinawite (tetragonal FeS) which typically precipitates as a nano-particulate phase; greigite $\left(\mathrm{Fe}_{3} \mathrm{~S}_{4}\right.$, inverse spinel structure) which can form from the solid state transformation of mackinawite; and pyrite $\left(\mathrm{FeS}_{2}\right)$ which is typically micro-particulate due to its rapid crystal growth and is the most common iron sulphide in sediments [36, 37].

\section{Iron Mineral Interactions with Sediment Pollutants}

Because iron mineral stability is strongly dependent on the ambient redox properties of the sediment, large differences in the $\mathrm{Fe}$ mineral interactions with various inorganic and organic contaminants can be expected between oxic, sub-oxic b

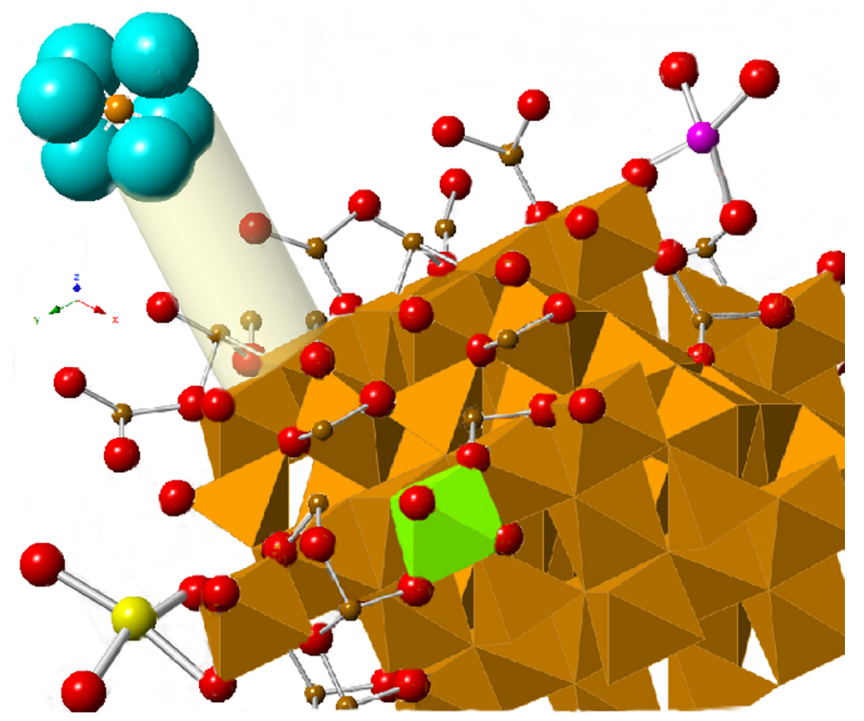

outer-sphere bonds with ferrihydrite. As(V) forms inner-sphere bidentate and minor monodentate bonds with goethite, and inner-sphere bidentate bonds with ferrihydrite [31, and references therein]. Co-precipitation and occlusion is another mechanism for contaminant sequestration (e.g. $\mathrm{Ni}$ (II) in ferrihydrite structure). Figures are orientated facing the 111 plane

and anoxic sediment horizons. The largest volumes of work have been conducted on $\mathrm{Fe}$ oxides which are stable in the oxic horizons and which are well known for their adsorption capacity for metals and metalloids in soils and in experimental systems. Because of the complexities associated with sampling and analysis [38], a far smaller volume of work has been conducted on the pollutant-mineral interactions in reduced and in reducing sediment horizons, where Fe carbonates, phosphates and sulphides are the dominant Fe minerals present.

\section{Contaminant-Mineral Interactions in Oxic Sediments}

\section{Arsenic}

Arsenic exists in soils and sediments predominantly as inorganic arsenate $(\mathrm{As}(\mathrm{V}))$ and arsenite $(\mathrm{As}(\mathrm{III}))$. It is discussed here separately from toxic trace metals because of its classification as a metalloid because it is characterised by a strong and well-studied association with Fe oxides and because As toxicity has been highlighted as a major and currently occurring human health concern (e.g. Bangladeshi drinking water [39]). Arsenite is more toxic and more mobile than $\mathrm{As}(\mathrm{V})$ [40], and both forms can be more toxic than many of the organoarsenical moieties [41]. Arsenic toxicity can be mitigated by immobilisation through adsorption to or co-precipitation with different Fe (oxy-hydr)oxide mineral phases [15]. Although both forms show a strong geochemical association 


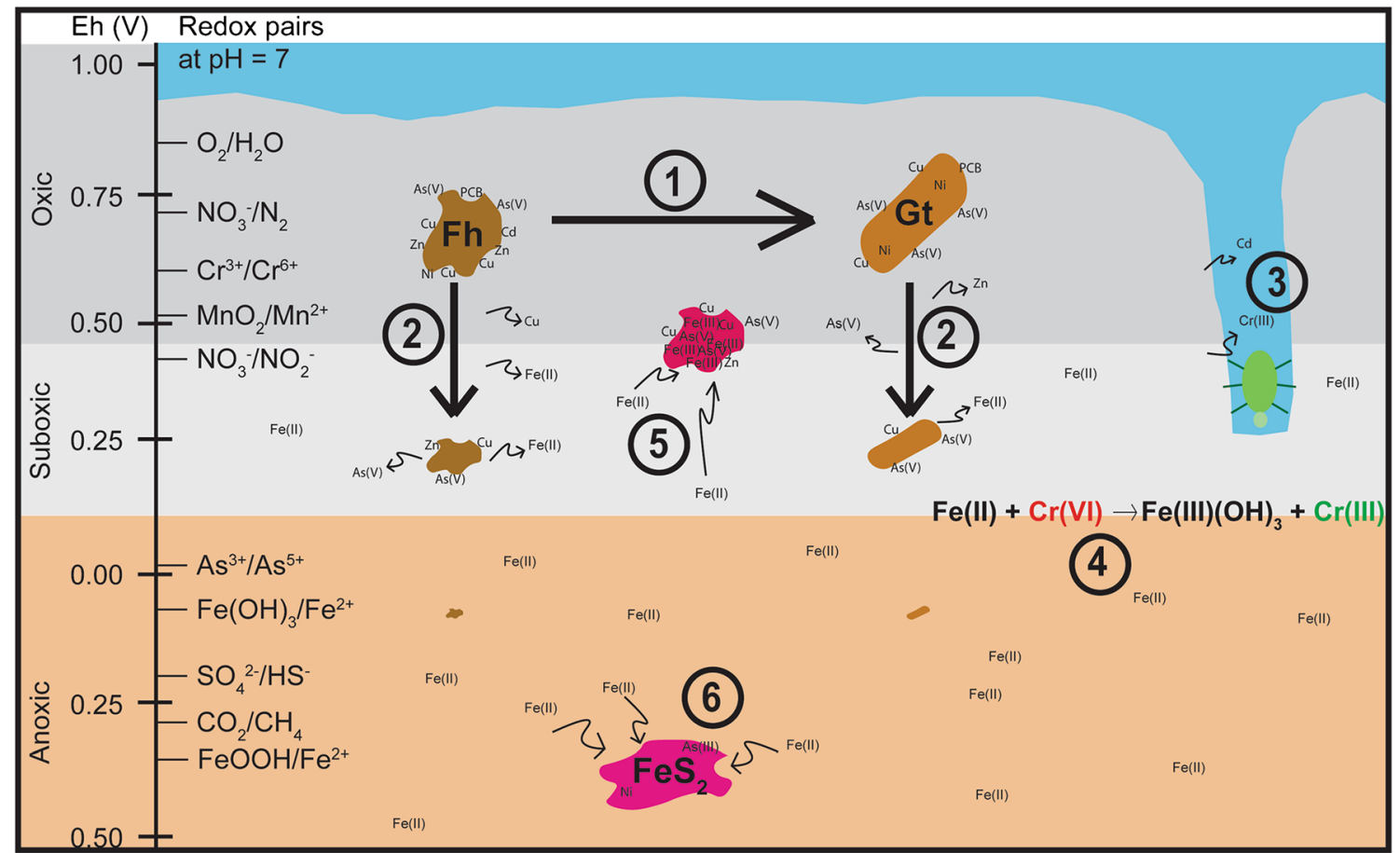

Fig. 2 Interactions between Fe mineral phases and inorganic and organic contaminants and the transformations and variations that occur due to sediment biogeochemistry. (1) Ageing transformations from poorly crystalline phases (e.g. ferrihydrite, schwertmannite) to more crystalline phases (e.g. goethite, hematite) typically lead to an expulsion of adsorbed contaminants due to decreases in mineral surface area. However, divalent cations associated with the more crystalline phases typically become more recalcitrant [34]. (2) Reductive dissolution of Fe oxide minerals leads to the release of adsorbed and co-precipitated contaminants, with a concomitant release of reduced Fe(II) into solution. (3) Disturbances to the sediment structure during diagenesis (e.g. bioturbation, dredging and sediment re-suspension) can lead to speciation changes (due to infiltrating

with Fe, the oxidised form $(\mathrm{As}(\mathrm{V}))$ is more strongly bound to Fe (oxy-hydr)oxide surfaces than As(III). This is achieved through the formation of bidentate inner-sphere bonding coordination of $\mathrm{As}(\mathrm{V})$ at the oxide surface $[15,42]$, although monodentate bonding has also been reported, typically when the $\mathrm{pH}$ is greater than eight [42].

Aside from the effects of As speciation and $\mathrm{pH}$, other chemical and mineralogical factors can affect the stability and extent of As adsorption. For example, among the different $\mathrm{Fe}$ (oxy-hydr)oxides, ferrihydrite is known to have the highest sorption capacity for As due to its high surface area [17, 43], and Al substitution for $\mathrm{Fe}$ (III) in the various oxide mineral structures has been shown to decrease As adsorption [44]. Arsenic adsorption can further be decreased by the presence of $\mathrm{Fe}$ binding ligands (e.g. dissolved organic matter [45] and inorganic ligands such as phosphates [46]) which compete for surface bonding sites on $\mathrm{Fe}$ (oxy-hydr)oxide surfaces. In contrast, the presence of $\mathrm{Zn}$ can significantly increase the adsorption of As by goethite through the formation of $\mathrm{Zn}-\mathrm{AsO}_{4}$ surface complexes [47].
$\mathrm{O}_{2}$ ) and can also lead to release of contaminants into the water column, thus posing a threat to aquatic organisms. (4) The released flux of $\mathrm{Fe}$ (II) can act as an electron donor during coupled redox transformation of contaminant phases. This is the premise on which the $\mathrm{Fe}(0)$ and $\mathrm{Fe}(\mathrm{II})$ amendment strategies are based. (5) The reduced Fe(II) flux can also reprecipitate at the redox boundary to form poorly crystalline phases (including mixed metal species such as $\mathrm{FeAsO}_{4}-\mathrm{H}_{2} \mathrm{O}$ ) which can incorporate various trace metal contaminants. (6) Under highly anaerobic conditions, sulphur speciation has the strongest control on contaminant chemistry. Pyrite readily precipitates and can incorporate trace metals such as Co and Ni. Effect of Eh on redox couples is after [35]

\section{Trace Metal Pollutants}

Unlike organic pollutants which can be degraded, trace metals (e.g. $\mathrm{Cd}, \mathrm{Cr}, \mathrm{Cu}, \mathrm{Ni}, \mathrm{Pb}, \mathrm{Sn}, \mathrm{Zn}$ ) remain persistent in sediment systems, where they can pose severe toxicity risks to benthic and aquatic organisms [20]. These trace elements must thus either be removed from the system (relocation and/or ex situ remediation) or their toxicity must be mitigated through changing their speciation (e.g. $\mathrm{Cr}(\mathrm{VI})$ to $\mathrm{Cr}(\mathrm{III})$ ) or through decreasing their mobility (i.e. through geochemical stabilisation with sediment constituents such as Fe (oxy-hydr)oxide phases). Relative to As, trace metals are not as strongly adsorbed to Fe mineral surfaces and the stability of these various adsorption complexes is often more strongly dependent on parameters (especially $\mathrm{pH}$ ) other than the $\mathrm{Fe}$ mineralogy and concentration [48]. For example, Cd(II) is known to form edge-sharing and corner-sharing inner-sphere complexes with goethite and ferrihydrite [16], yet in marine sediments with high $\mathrm{Cl}^{-}$activity, the formation of mobile Cdchloride complexes inhibits surface adsorption to sediment minerals [49]. 
Chromium exists in sediment horizons in either its trivalent (Cr(III)) or more toxic hexavalent (Cr(VI)) form [e.g. 50], and both species have been shown to interact with Fe minerals [51]. Depending on Fe (oxy-hydr)oxide mineralogy, bonding interactions range from inner-sphere monodentate and bidentate coordination to epitaxial and non-epitaxial precipitation on oxide surfaces (see Table 1 in [31]). Notably, Cr(VI) toxicity can be mitigated by reductive precipitation at $\mathrm{Fe}(\mathrm{II})$ structural sites on magnetite surfaces [52]. Ferric (oxy-hydr)oxide surfaces can also play a strong role in catalysing the reduction of $\mathrm{Cr}(\mathrm{VI})$ by $\mathrm{Fe}(\mathrm{II})$ resulting in the surface precipitation of $\mathrm{Cr}(\mathrm{OH})_{3}$ [53]. Finally, adsorption of $\mathrm{Cr}$ (III) to $\mathrm{Fe}$ (oxy-hydr)oxide surfaces can inhibit its Mn-oxide-mediated oxidation to toxic $\mathrm{Cr}(\mathrm{VI})$ [54].

Adsorption of divalent metal ions (e.g. $\mathrm{Cu}(\mathrm{II}), \mathrm{Pb}(\mathrm{II})$, $\mathrm{Zn}(\mathrm{II})$ ) to Fe (oxy-hydr)oxide surfaces is most strongly controlled by ambient sediment $\mathrm{pH}$. Because the point of zero charge (PZC) for these minerals occurs at circumneutral $\mathrm{pH}$ [12], their surfaces become increasingly positive as $\mathrm{pH}$ decreases, thereby decreasing the likelihood of interaction with cationic metals. Fe (oxy-hydr)oxides are generally regarded as being a good sink for $\mathrm{Cu}$ [20] and have been shown to form inner-sphere complexes with goethite and poorly crystalline Fe oxy-hydroxides (see Table 1 in [31]). Adsorption of $\mathrm{Cu}$ has also been shown to block the complexation of other divalent contaminants (i.e. $\mathrm{Zn}$ ) through competition for sorption sites on Fe (oxy-hydr)oxide surfaces [55]. Zn also forms innersphere complexes with Fe (oxy-hydr)oxides and the exact bonding configuration is strongly dependent on Fe mineralogy and $\mathrm{pH}[56,57]$. Similarly, $\mathrm{Pb}$ bonding interaction is partially controlled by mineralogy, forming bidentate edgesharing complexes with goethite [58] and multinuclear complexes with ferrihydrite [59]. In spite of the formation of these inner-sphere bonds to Fe (oxy-hydr)oxides, $\mathrm{Pb}$ shows a much stronger bonding affinity for Mn oxides which are thus up to 40 times more efficient in stabilising this toxic metal [60, 61].

\section{Organic Pollutants}

Iron oxides are known to have strong geochemical interactions and associations with organic matter in soils [62] and in deposited and suspended sediments [63, 64]. The interactions between $\mathrm{Fe}$ minerals and organic contaminants (e.g. polycyclic aromatic hydrocarbons, polychlorinated biphenols, antibiotics etc.) are complicated by the wide range in organic contaminant structure and functional group chemistry. However, multiple studies have shown that $\mathrm{Fe}$ mineral phases can adsorb organic contaminants thereby stabilising their mobility in soil and sediment systems [e.g. 13, 14, 65]. For antibiotic contaminant phases, the bonding interaction is attributed to chemical complexation at the Fe oxide surfaces $[14,65]$ and can be inhibited by the presence of competing ions (e.g. P, Ca [14]). However, the formation of these surface complexes may not always lead to contaminant immobilisation, as the complexation can lead to ligand-promoted dissolution of $\mathrm{Fe}$ mineral phases [66]. Fe minerals can also play a catalytic role in organic pollutant degradation through oxidative Fenton-like reaction pathways [67, 68].

\section{Contaminant-Mineral Interactions in Sub-Oxic and Anoxic Sediments}

At depths below the upper-most oxic sediment layer, the sediment redox potential decreases, causing a decrease in the stability of $\mathrm{Fe}$ (III) mineral phases with a concomitant increase in the stability of porewater $\mathrm{Fe}(\mathrm{II})$ and reduced secondary minerals (e.g. vivianite $\left(\mathrm{Fe}_{3}\left(\mathrm{PO}_{4}\right)_{2}\right.$; siderite $\left(\mathrm{FeCO}_{3}\right)$ and $\mathrm{Fe}(\mathrm{II})$ sulphides). This reduction of the Fe(III) (oxy-hydr)oxide minerals and production of $\mathrm{Fe}$ (II) gives rise to a number of dynamic chemical processes that can have impact on the speciation and mobility of sediment pollutants (Fig. 2). Importantly, the reductive dissolution of Fe (oxy-hydr)oxide minerals leads to the release of adsorbed and co-precipitated pollutants into the pore waters, potentially representing a significant source of pollutants into the overlying water column [69]. For example, the reducing conditions associated with flooded rice paddies results in the release of high concentrations of $\mathrm{As}$ (III) to the soil porewater [70, 71]. The released flux of $\mathrm{Fe}$ (II) can affect contaminant fate in two ways: direct interaction with the contaminants through coupled redox transformation [35] or in situ re-oxidation to precipitate oxide phases with co-precipitated contaminants [72].

Interaction between reduced $\mathrm{Fe}$ and pollutants has been well studied, and a range of remediation techniques utilises this principle to stabilise inorganic pollutants and degrade organic pollutants through oxidation by $\mathrm{Fe}(\mathrm{II})$ (e.g. $\mathrm{FeSO}_{4}$ and $\mathrm{Fe}(0)$ amendment technologies (Table 1; [18]). For example, $\mathrm{Fe}(\mathrm{II})$ can facilitate the reduction of $\mathrm{Cr}(\mathrm{VI})$ to its less toxic $\mathrm{Cr}$ (III) form [135], and $\mathrm{Cu}$ (II) has been shown to reduce to $\mathrm{Cu}(\mathrm{I})$ [136] and to native copper [137]. $\mathrm{Fe}(\mathrm{II})$ is not significant in reducing $\mathrm{As}(\mathrm{V})$ to the more toxic $\mathrm{As}(\mathrm{III})$ form [138]; however, the reverse reaction can be catalysed under oxic and anoxic conditions when As(III) is oxidised by enhanced $\mathrm{Fe}(\mathrm{II})$ reactivity at a $\mathrm{Fe}$ (III) (oxy-hydr)oxide mineral surface [139, 140].

The Fe(II) flux can also re-oxidise to precipitate in situ a variety of poorly crystalline mineral phases (e.g. schwertmannite $\left(\mathrm{Fe}_{8} \mathrm{O}_{8}(\mathrm{OH})_{6}\left(\mathrm{SO}_{4}\right) \cdot \mathrm{nH}_{2} \mathrm{O}\right)$, green-rust (mixed-valence amorphous phase) and ferrihydrite) depending on the ambient solution properties (e.g. pH, Eh, Fe and contaminant concentrations). Ferrihydrite is known to incorporate $\mathrm{As}, \mathrm{Cd}, \mathrm{Cu}, \mathrm{Pb}$ and $\mathrm{Zn}$ during precipitation [e.g. 141] with many of the divalent cations becoming less extractable upon ageing to goethite [34]. Similarly, ageing of 
Table 1 Non-exhaustive list of laboratory and field experiments involving Fe materials interacting with common soil and sediment contaminants

\begin{tabular}{|c|c|c|c|}
\hline Contaminant & Iron treatment & Ref. & Amendment ratio, effectiveness and additional notes \\
\hline \multirow[t]{15}{*}{ As } & \multirow[t]{4}{*}{ FeSO4+lime } & [73] & $\begin{array}{l}\mathrm{Fe} \text { amendment ratio (Fe:As) }=2: 1 \text {; depending on soil type, } 97.2-99.5 \% \text { of As stabilised without } \mathrm{CaCO}_{3} \\
\text { addition, } 95.5-99.4 \% \text { of As stabilised with the addition of } \mathrm{CaCO}_{3}\end{array}$ \\
\hline & & {$[74]$} & $\begin{array}{l}\text { Additions resulting in } 0.2 \% \mathrm{Fe} \text { oxides in soils resulted in } 22 \% \text { reduction in As uptake by various } \\
\text { vegetables }(0.5 \% \text { concentration led to a } 32 \% \text { reduction in As uptake })\end{array}$ \\
\hline & & [75] & Amendments of $1.89 \% \mathrm{FeSO}_{4}$ and $0.68 \%$ lime resulted in a $84 \%$ reduction in lettuce As concentration \\
\hline & & [76] & Amendment added at $1 \mathrm{wt} \%$ concentration, $68.2-98.0 \%$ reduction in uptake by ryegrass \\
\hline & \multirow[t]{2}{*}{$\begin{array}{l}\text { Synthetic Fe oxy- } \\
\text { hydroxides }\end{array}$} & [77] & $\begin{array}{l}1 \mathrm{wt} \% \text { resulting in } 65-97 \% \text { As stabilisation depending on soil type (5 wt } \% \text { addition results in } 78-97 \% \text { As } \\
\text { stabilisation) }\end{array}$ \\
\hline & & [78] & 1 and $3 \mathrm{wt} \%$, soluble As concentrations decreased by $\sim 65 \%$ \\
\hline & $\mathrm{Fe}(0)+$ compost + beringite & [79] & $\begin{array}{l}\text { Amended with } 1 \mathrm{wt} \% \mathrm{Fe}(0), 5 \mathrm{wt} \% \text { organic matter and } 5 \mathrm{wt} \% \text { beringite, focus on the effects on } \\
\text { phytoremediation }\end{array}$ \\
\hline & \multirow[t]{6}{*}{$\mathrm{Fe}(0)$} & {$[80]$} & As removal capacity $=7.5 \mathrm{mg}$ As per gramme of $\mathrm{Fe}(0)$ \\
\hline & & {$[81]$} & Amendment added at $1 \mathrm{wt} \%$ concentration leading to a $60-69 \%$ decrease in As leachability \\
\hline & & {$[82]$} & $\begin{array}{l}\text { Column-based field experiments, up to } 4.4 \mathrm{mg} \text { As accumulated per } \mathrm{g} \mathrm{Fe}(0)+\text { sand, decreasing aqueous As } \\
\text { concentration to } 10 \mu \mathrm{g} / \mathrm{L}\end{array}$ \\
\hline & & {$[83]$} & $\begin{array}{l}1 \mathrm{~g} \mathrm{Fe}(0) \text { added to } 41.64 \mathrm{~mL} \text { solution }(2 \mathrm{mg} / \mathrm{L} \mathrm{As}) \text {; experimental system comparing effectiveness of } \\
\text { various engineered } \mathrm{Fe}(0) \text { particles }\end{array}$ \\
\hline & & {$[84]$} & Experimental work showing both oxidation and reduction of As(III) in contact with $\mathrm{Fe}(0)$ nanoparticles \\
\hline & & {$[85]$} & $\begin{array}{l}1 \mathrm{wt} \% \text { amendment ratio resulting in significant reduction of As in leachates }(98 \%) \text {, porewater }(99 \%) \text { and } \\
\text { plant shoots }(84 \%)\end{array}$ \\
\hline & Ferrihydrite & {$[86]$} & $1-2 \mathrm{wt} \%$ added to soils, no appreciable change in As extractability \\
\hline & $\mathrm{Fe}(0)+$ beringite & [87] & $1 \% \mathrm{Fe}(0)+5 \%$ beringite, results in $87 \%$ reduction in As extractability after 6 years \\
\hline \multirow[t]{8}{*}{$\mathrm{Cd}$} & \multirow[t]{3}{*}{$\mathrm{Fe}(0)$} & {$[88]$} & $1.0 \mathrm{nM} \mathrm{Cd}$ solution loaded with $0.5 \mathrm{~g} / \mathrm{L} \mathrm{Fe}(0)$; maximum adsorption to $\mathrm{Fe}(0)$ was $225 \mathrm{mg} / \mathrm{g}$ \\
\hline & & [89] & $\begin{array}{l}\text { Soil amended with } 2 \text { wt } \% \mathrm{Fe}(0), 4.1-36.7 \% \text { improvement in immobilisation/extractability depending on } \\
\text { test used }\end{array}$ \\
\hline & & {$[90]$} & Soil amended with $1 \mathrm{wt} \% \mathrm{Fe}(0)$, up to $30 \%$ decrease in mobile $\mathrm{Cd}$ \\
\hline & Steel sludge & [91] & Amended with $0.6 \mathrm{wt} \%$ steel sludge, decreased Cd accumulation in plants by $58.8 \%$ \\
\hline & \multirow[t]{4}{*}{ Red mud } & [92] & $\begin{array}{l}\text { Soil amended with } 0.25-0.2 \mathrm{wt} \% \text { red mud, exchangeable Cd reduced by } 42-69 \% \text { depending on soil } \\
\text { properties }\end{array}$ \\
\hline & & [93] & Soil amended with $0.25-0.2 \mathrm{wt} \%$ red mud, bioaccumulation in plant leaves decreased on average by $57 \%$ \\
\hline & & [94] & $\begin{array}{l}\text { Concentration of } 10 \mathrm{~g} / \mathrm{kg} \text { red mud added to soil, Cd extractability decreased by } 70 \% \text { and } \mathrm{Cd} \text { plant } \\
\text { extractability by } 38-87 \%\end{array}$ \\
\hline & & [95] & Soil amended with $5 \mathrm{wt} \%$ red mud resulted in $\sim 76 \%$ reduction in porewater $\mathrm{Cd}$ after 25 months \\
\hline \multirow[t]{6}{*}{$\mathrm{Cu}$} & Ferrihydrite & [96] & $10 \mathrm{wt} \%$ additions of ferrihydrite reduced $\mathrm{Cu}$ extractability by $92 \%$ \\
\hline & \multirow[t]{2}{*}{ Red mud } & [97] & Soils amended with $0.25,2$ and $5 \mathrm{wt} \%$ red mud, labile pool of $\mathrm{Cu}$ decreased by $30 \%$ \\
\hline & & [95] & Soil amended with $5 \mathrm{wt} \%$ red mud resulted in $\sim 37 \%$ reduction in porewater $\mathrm{Cd}$ \\
\hline & \multirow[t]{3}{*}{$\mathrm{Fe}(0)$} & {$[85]$} & Soil stabilised with $1 \mathrm{wt} \% \mathrm{Fe}(0)$, reduced $\mathrm{Cu}$ leaching by $93 \%$ but increased its bioavailability \\
\hline & & {$[90]$} & Soil amended with $1 \mathrm{wt} \% \mathrm{Fe}(0), 10 \%$ decrease in mobile $\mathrm{Cu}$ \\
\hline & & [98] & $\begin{array}{l}\text { Soil stabilised with } 2 \text { wt } \% \mathrm{Fe}(0) \text { and } 5 \mathrm{wt} \% \text { compost, recalcitrant Fe oxy-hydroxide bound } \mathrm{Cu} \text { increased } \\
\text { from } 22 \text { to } 50 \%\end{array}$ \\
\hline
\end{tabular}
depending on nature of $\mathrm{OM}$

[100] Experimental batch experiments; removal capacity of 50-180 mg Cr per gramme $\mathrm{Fe}(0)$

[101] $10: 3 \mathrm{Fe}(0)$ to $\mathrm{Cr}$ loading ratio resulted in $90 \%$ adsorption of $\mathrm{Cr}$ in three days

[102] Experimental work, variable rate constants reported for different $\mathrm{Fe}: \mathrm{Cr}$ amendment ratios and for different $\mathrm{Fe}(0)$ size fractions

[92] Soil amended with $0.25-0.2 \mathrm{wt} \%$ red mud, exchangeable $\mathrm{Pb}$ reduced by $30-92 \%$ depending on soil properties

[95] Soil amended with $5 \mathrm{wt} \%$ red mud resulted in $\sim 75 \%$ reduction in porewater $\mathrm{Pb}$ after 25 months

[93] Soil amended with $0.25-0.2 \mathrm{wt} \%$ red mud, bioaccumulation of $\mathrm{Pb}$ in plant leaves decreased by $\sim 68 \%$ in two plants

[81] Amendment added at $1 \mathrm{wt} \%$ concentration, limited effect on $\mathrm{Pb}$ leachability

[89] Soil amended with $2 \mathrm{wt} \% \mathrm{Fe}(0), 1.7-25.1 \%$ improvement in immobilisation/extractability depending on test used

[78] 1 and $3 \mathrm{wt} \%$, porewater and lexiviate $\mathrm{Pb}$ concentrations decreased by $>90 \%$

[103] Variable Fe(II) bearing phases tested 
Table 1 (continued)

\begin{tabular}{|c|c|c|c|}
\hline Contaminant & Iron treatment & Ref. & Amendment ratio, effectiveness and additional notes \\
\hline & Iron hydroxides & [104] & $\begin{array}{l}\text { Experimental work with variable parameters tested; } 0.1 \mathrm{~g} / \mathrm{L} \mathrm{Fe} \text { added } 50 \mathrm{mg} / \mathrm{L} \mathrm{Se} \text { solution results in } \\
\text { specific removal of } 155 \mathrm{mg} / \mathrm{g}\end{array}$ \\
\hline & $\mathrm{Fe}(0)$ & [105] & Batch experiments; nano $\mathrm{Fe}(0)$ uptake capacity of Se up to $0.1 \mathrm{Se}: \mathrm{Fe}$ molar ratio \\
\hline & $\mathrm{Fe}(0) / \mathrm{Ni}$ & [104] & $\begin{array}{l}\text { Experimental work with variable parameters tested; } 0.1 \mathrm{~g} / \mathrm{L} \text { Fe added } 50 \mathrm{mg} / \mathrm{L} \text { Se solution results in } \\
\text { specific removal of } 225 \mathrm{mg} / \mathrm{g}\end{array}$ \\
\hline \multirow[t]{4}{*}{ U } & $\mathrm{Fe}(0)$ & [106] & $0.05 \mathrm{~g} \mathrm{Fe}(0)$ added to $400 \mathrm{~mL}$ of effluent, achieves $98 \%$ removal of $\mathrm{U}$ from solution within $48 \mathrm{~h}$ \\
\hline & & [107] & $\begin{array}{l}\text { Reacted solution contained } 200 \mu \mathrm{M} \mathrm{U}(\mathrm{VI}) \text { and } 492.3 \mu \mathrm{M} \text { nanoFe, }>93 \% \text { of } \mathrm{U} \text { removed from solution } \\
\text { within } 10 \text { min at } \mathrm{pH} 6.9\end{array}$ \\
\hline & & [108] & $0.1 \mathrm{~g}$ of nano $\mathrm{Fe}(0)$ added to $400 \mathrm{~mL}$ U-contaminated water; $98 \%$ removal from water \\
\hline & Magnetite & [108] & $0.1 \mathrm{~g}$ of nano magnetite added to $400 \mathrm{~mL} \mathrm{U}$-contaminated water; $<20 \%$ removal from water \\
\hline \multirow[t]{4}{*}{ Zn } & Red mud & [94] & $\begin{array}{l}\text { Concentration of } 10 \mathrm{~g} / \mathrm{kg} \text { red mud added to soil, } \mathrm{Zn} \text { extractability decreased by } 89 \% \text { and } \mathrm{Cd} \text { plant } \\
\text { extractability by } 50-81 \%\end{array}$ \\
\hline & $\mathrm{Fe}(0)$ & [81] & Amendment added at $1 \mathrm{wt} \%$ concentration, limited effect to $\mathrm{Zn}$ leachability \\
\hline & & [90] & Soil amended with $1 \mathrm{wt} \% \mathrm{Fe}(0)$, up to $31 \%$ decrease in mobile $\mathrm{Zn}$ \\
\hline & Amorphous iron oxides & [78] & 1 and $3 \mathrm{wt} \%$, porewater and lexiviate $\mathrm{Zn}$ concentrations decreased by $>90 \%$ \\
\hline Atrazine & $\mathrm{Fe}(0)$ & [109] & $\begin{array}{l}30 \mathrm{mg} / \mathrm{L} \text { atrazine solution treated with } 2 \%(w / v) \text { nano } \mathrm{Fe}(0) \text { and } 5 \%(w / v) \mathrm{Fe}(0) ; \sim 50 \% \text { and } 20 \% \\
\text { removal efficiencies, respectively }\end{array}$ \\
\hline \multirow[t]{3}{*}{$\begin{array}{l}\text { Chlorinated } \\
\text { methane }\end{array}$} & $\mathrm{Fe}(0)$ & [110] & $\begin{array}{l}\text { Batch experiments; } 1 \mathrm{~g} \mathrm{Fe}(0) \text { reacted with } 2 \mathrm{~mL}(100-800 \mathrm{uM}) \text { stock diluted to } 40 \mathrm{~mL} \text {; degradation rates } \\
\text { reported }\end{array}$ \\
\hline & & [111] & $\begin{array}{l}\text { Batch experiments; } 0.25 \mathrm{~g} \mathrm{Fe}(0) \text { reacted with } 10 \mu \mathrm{L}(0.1 \mathrm{mM}) \text { stock in } 20 \mathrm{~mL} \text { DI water; complete } \\
\quad \text { reduction of organics between } 20 \text { and } 100 \mathrm{~h}\end{array}$ \\
\hline & Magnetite & [112] & Batch experiments; $25 \mathrm{~g} / \mathrm{L}$ magnetite reacted with $20 \mu \mathrm{M} \mathrm{CCl}_{4}$, rate constants determined \\
\hline \multirow[t]{2}{*}{$\begin{array}{l}\text { Chlorinated } \\
\text { ethane }\end{array}$} & $\mathrm{Fe}(0)$ & [113] & $\begin{array}{l}\text { Batch experiments, variable Fe particle loading }(0.08-0.40 \mathrm{~g} / \mathrm{L}) \text { tested with variable chlorinated ethane } \\
\text { speciation and initial concentration. }\end{array}$ \\
\hline & $\mathrm{Fe} / \mathrm{Pd}$ & [114] & $\begin{array}{l}5 \mathrm{~g} / \mathrm{L} \mathrm{Fe} \text { nanoparticles reacted with } 20-30 \mathrm{~g} / \mathrm{L} \text { chlorinated ethanes, extent of degradation varied according } \\
\text { to organic speciation }\end{array}$ \\
\hline \multirow[t]{11}{*}{$\begin{array}{l}\text { Chlorinated } \\
\text { ethene }\end{array}$} & $\mathrm{Fe}(0)$ & [115] & $\begin{array}{l}\text { Column experiment: } 15 \mathrm{wt} \% \mathrm{Fe}(0) \text { in silica matrix, degradation of various trichloroethene concentrations } \\
\text { tested }\end{array}$ \\
\hline & & [116] & Column experiments; trichloroethene reaction rates reported \\
\hline & & [117] & $15 \mathrm{~g} \mathrm{Fe}(0)$ reacted with $60 \mathrm{~mL}$ of solution (conc. $=2 \mathrm{mg} / \mathrm{L} \mathrm{TCE}$ ), results in complete degradation of TCE \\
\hline & Disordered $\mathrm{Fe}(0)$ & [118] & Batch experiments under excess $\mathrm{Fe}$ and Fe limited conditions, variable results \\
\hline & Iron+palladidized-iron & [114] & $\begin{array}{l}5 \mathrm{~g} / \mathrm{L} \mathrm{Fe} \text { nanoparticles reacted with } 30 \mathrm{~g} / \mathrm{L} \text { chlorinated ethenes, degradation results in }<1 \% \text { chlorinated } \\
\text { intermediates }\end{array}$ \\
\hline & & [119] & Batch experiments with variable Fe and TCE loadings, effects of cellulose stabilisers tested \\
\hline & Nano Fe+Ni particles & [120] & $350 \mathrm{mg} / \mathrm{L}$ trichloroethene reacted with $1 \mathrm{~g} / \mathrm{L} \mathrm{Fe} / \mathrm{Ni}$ particles results in complete dechlorination in $576 \mathrm{~h}$ \\
\hline & & [121] & $0.1 \mathrm{~g} \mathrm{Fe} / \mathrm{Ni}$ nanoparticles reacted with $40 \mathrm{~mL}$ of $24 \mathrm{ppm}$ trichloroethene; $75 \%$ dechlorination in $2 \mathrm{~h}$ \\
\hline & $\mathrm{Fe}(\mathrm{II}) /$ hematite & [122] & 200-260 mM Fe oxide reacted with $0.25 \mathrm{mM}$ TCE, complete degradation after 6 days \\
\hline & Fe(0)-silica composite & [123] & $\begin{array}{l}0.4 \mathrm{~g} \text { Fe particles reacted with } 10 \mathrm{~mL} \text { solution containing } 20 \mathrm{ppm} \text { TCE, complete degradation of TCE } \\
\text { achieved }\end{array}$ \\
\hline & Granular iron & [124] & Column experiment, $>97 \%$ TCE removal efficiency \\
\hline $\begin{array}{c}\text { Chlorinated } \\
\text { benzene }\end{array}$ & $\mathrm{Cu} / \mathrm{Fe}$ particles & [125] & $\begin{array}{l}\sim 0.2 \mathrm{~g} \text { Fe particles reacted with } 5 \mathrm{~mL} \text { of } 0.2 \mathrm{mg} / \mathrm{L} \text { hexachlorobenzene solution, } 98 \% \text { dechlorination } \\
\text { within } 48 \mathrm{~h}\end{array}$ \\
\hline \multirow{4}{*}{$\begin{array}{l}\text { Polychlorinated } \\
\text { biphenyls }\end{array}$} & $\mathrm{Fe}(0)$ & [126] & $1.5 \mu \mathrm{mol}$ PCB dry reacted with $0.5 \mathrm{~g} \mathrm{Fe}(0)$ powder, $95 \%$ dechlorination at $400{ }^{\circ} \mathrm{C}$ \\
\hline & Humic acid $+\mathrm{Fe}(0)$ & [127] & $\begin{array}{l}0.3 \mathrm{~g} \mathrm{Fe}(0) \text { added to } 40 \mathrm{~mL} \text { of } 5 \mathrm{mg} / \mathrm{L} \text { 4-chlorobiphenyl solution; } 86.3 \% \text { degradation in } 48 \mathrm{~h} \text { in the } \\
\text { presence of humics }\end{array}$ \\
\hline & $\mathrm{Pd} / \mathrm{Fe}$ & [128] & $\sim 2 \mathrm{~g} \mathrm{Fe} / \mathrm{Pd}$ particles reacted with $5 \mathrm{~mL}$ of $20 \mathrm{ppm}$ PCB solution, full degradation achieved \\
\hline & & [129] & $0.71 \mathrm{~g} / \mathrm{L} \mathrm{Fe} / \mathrm{Pd}$ loading able to fully degrade $15 \mathrm{mg} / \mathrm{L} \mathrm{PCB}$, insignificant reaction with unpalladized $\mathrm{Fe}$ \\
\hline DDT & Iron by-products & [130] & $150 \mathrm{~mL}$ of $5 \mathrm{mg} / \mathrm{L}$ DDT solution treated with $5 \%(w / v) \mathrm{Fe},>95 \%$ removal of DDT within 30 days \\
\hline DNAPL & Emulsified $\mathrm{Fe}(0)$ & [131] & $\begin{array}{l}\text { Field experiments, } 670 \text { gal of emulsion }(17 \% \mathrm{Fe}) \text { injected into } 15 \times 9.5 \times 10 \mathrm{ft} \text { volume; }>80 \% \mathrm{TCE} \\
\text { breakdown in } 90 \text { days }\end{array}$ \\
\hline \multirow[t]{3}{*}{ TNT } & $\mathrm{Fe}(0)$ & [132] & $\begin{array}{l}\text { Batch experiments, } 2 \mathrm{~g} \mathrm{Fe}(0) \text { reacted with } 1 \mathrm{~mL} \text { of } 10^{-3} \mathrm{M} \text { nitrobenzene diluted to } 60 \mathrm{~mL} \text {; rate constants } \\
\text { reported }\end{array}$ \\
\hline & & [133] & $1 \%(w / v) \mathrm{Fe}(0)$ removed $70 \mathrm{mg} / \mathrm{L}$ TNT from aqueous solution within $8 \mathrm{~h}$ \\
\hline & & [134] & $\begin{array}{l}\text { Batch experiments, } 17-100 \mathrm{~g} / \mathrm{L} \mathrm{Fe}(0) \text { reacted with 4-352 } \mu \mathrm{M} \text { TNT; complete degradation at high Fe:TNT } \\
\text { ratios }\end{array}$ \\
\hline
\end{tabular}


schwertmannite to goethite leads to increased $\mathrm{Cr}$ incorporation in the mineral structure, whereas $\mathrm{Cu}, \mathrm{Ni}$ and $\mathrm{Zn}$ concentrations have been found to decrease with ageing [142]. In sediment systems with high As concentrations, a number of discreet coprecipitated mineral phases are known to form (e.g. $\mathrm{FeAsO}_{4}$ $\mathrm{H}_{2} \mathrm{O}, \mathrm{FeAsO}_{4} \cdot 2 \mathrm{H}_{2} \mathrm{O}$ and $\left.\mathrm{Fe}_{3}\left(\mathrm{AsO}_{4}\right)_{2}\right)$, many of which are more stable and less soluble than the complexes that form when As is merely adsorbed to $\mathrm{Fe}$ (oxy-hydr)oxide surfaces $[34,36]$.

Under increasingly anoxic conditions, sulphate reduction proceeds thus causing the sediments to become sulphidic and leading to the precipitation of various sulphide mineral phases. The precipitation of metal sulphides in anoxic sediments is controlled by the speed of the metals' water exchange reaction kinetics: $\mathrm{Cd}, \mathrm{Cu}, \mathrm{Pb}$ and $\mathrm{Zn}$ sulphides typically precipitate before the formation of pyrite $\left(\mathrm{FeS}_{2}\right)$ whereas $\mathrm{Co}$ and $\mathrm{Ni}$ have slower reaction kinetics and can be incorporated into the pyrite structure $[143,144]$. Mackinawite and greigite are also known to incorporate variable amounts of $\mathrm{Cu}, \mathrm{Co}$ and $\mathrm{Ni}$ $[36,145]$. Reduced As is incorporated into the pyrite structure, whereas reduced $\mathrm{Cr}$ is not chalcophyllic and therefore does not associate with precipitating pyrite [143]. Pyrite shows relatively slow dissolution kinetics and thus represents a relatively good sink for co-precipitated and occluded contaminant phases. Furthermore, the pyrite mineral surface can also play a role in contaminant transformation [146] and sorption [147] processes.

\section{Iron-Based Remediation of Contaminated Sediments}

Based on the chemical and mineralogical interactions of natural Fe with contaminant phases, a range of techniques has become available in the last two decades to treat contaminated sediments and soils using iron amendment strategies (Table 1). These techniques exploit either the adsorption or reduction properties of $\mathrm{Fe}$ [148-150] and can be applied as in situ [23] or ex situ [24] remediation strategies. The efficiency of either pathway is controlled by factors affecting the biogeochemical cycling of iron [151].

Sorption-based technologies typically utilise the known associations and chemical bonding interactions between mineral surfaces and toxic metals and metalloids, as described in 'Iron Mineral Interactions with Sediment Pollutants' section. These remediation techniques are thus used as in situ amendments to immobilise toxic metal(loid)s and to reduce their bioavailability in contaminated sediments [e.g. 19], and their efficiency is partially controlled by the mineralogy of the Fe mineral amendment. Due to their high specific surface areas, amorphous $\mathrm{Fe}$ (oxy-hydr)oxides are the most effective amendment when considering sorption capacity, yet their long-term stability may be compromised by contaminant release during ageing and/or recrystallization (e.g. As, $\mathrm{Cu}, \mathrm{Zn}$, Ni lost to solution during the schwertmannite to goethite transformation [142, 152]. However, dynamic recrystallization of $\mathrm{Fe}$ minerals (e.g. during ageing) is known to have complex effects on trace metal redistribution [153] and can represent an important trapping mechanism (e.g. for As [70]). Overall, when considering long-term immobilisation, the more crystalline $\mathrm{Fe}$ oxides are typically considered to be more effective, as they have shown better long-term retention of trace metals in soil systems [19, 34]. Mechanistically, the trace metal immobilisation can be achieved by inner-sphere or outer-sphere surface complexation reactions (Fig. 1), with inner-sphere coordination regarded as being more stable (Eqs. 1, 2, 4, 5). For example, the inner-sphere complexation reactions of $\mathrm{Ni}(\mathrm{II})$ and $\mathrm{Cr}(\mathrm{VI})$ with $\mathrm{Fe}$ mineral surfaces can be expressed as:

$$
\begin{aligned}
& \equiv \mathrm{FeOH}+\mathrm{Ni}^{2+} \leftarrow \longrightarrow \equiv \mathrm{FeO}-\mathrm{Ni}^{+}+\mathrm{H}^{+} \\
& \equiv \mathrm{FeOH}+\mathrm{Cr}_{2} \mathrm{O}_{7}{ }^{2-} \leftarrow \rightarrow \equiv \mathrm{Fe}-\mathrm{Cr}_{2} \mathrm{O}_{7}^{-}+\mathrm{OH}^{-}
\end{aligned}
$$

In chemical treatment methods, iron is generally used as a reductant for its ability to act as an electron donor (Fig. 3). From our review of literature, it is clear that the chemical treatment methods are primarily used for the treatment of contaminants in the porewater solution and limited research is available for their use for the treatment of soils and sediments [154]. Most commonly, the Fenton Reaction or a similar pathway is used (Fig. 3) where $\mathrm{Fe}(0)$ or $\mathrm{Fe}(\mathrm{II})$ are used to produce non-selective highly reactive oxidants for the breakdown of persistent organic compounds, such as PCBs, pesticides, fuels and explosives [148, 155, 156], and to change the speciation of redox reactive inorganic pollutants (e.g. $\mathrm{Cr}, \mathrm{Cu})$. Nano-zero-valent iron $(\mathrm{Fe}(0))$ is the most commonly used iron phase in these treatments because of its low standard electron potential $\left(\mathrm{E}^{\mathrm{o}}=\right.$ $-0.44 \mathrm{~V}$; [155]), which is lower than many trace metals and organic compounds [157]. Ferrous iron amendments including phosphates $[158,159]$, sulphates [73, 160] and sulphides [150] are also applicable to the reductive treatment of industrial wastes. In addition to their reductive capabilities, the introduction of reduced Fe phases to contaminated sediment porewater systems can lead to the in situ precipitation of $\mathrm{Fe}$ sulphides (under anoxic conditions) which can sequester $\mathrm{Co}, \mathrm{Ni}$ and other trace divalent trace metal cations [143, 144]. Similarly, under oxic conditions, the in situ precipitation of $\mathrm{Fe}$ oxyhydroxides can strongly stabilise contaminants through co-precipitation pathways. For example, iron sulphate amendments are particularly effective in this regard and can have better metal retention efficiency than $\mathrm{Fe}$ 


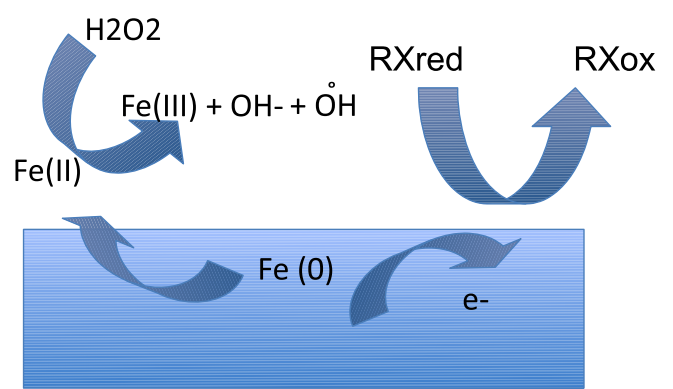

Fig. 3 Example of Fenton-like reaction catalysed by $\mathrm{Fe}(0)$ amendment

oxide amendments when compared in soil systems [81]. However, such $\mathrm{Fe}(\mathrm{II})$ amendments may require additional buffering capacity (e.g. lime additions) to counteract the acidity released during Fe oxy-hydroxide formation (Eq. 10), as some trace metals (e.g. $\mathrm{Cu}, \mathrm{Zn}$ ) show enhanced mobility with decreasing $\mathrm{pH}[160]$.

$4 \mathrm{FeSO}_{4}+\mathrm{O}_{2}+6 \mathrm{H}_{2} \mathrm{O} \rightarrow 4 \mathrm{FeOOH}+4 \mathrm{SO}_{4}{ }^{2-}+8 \mathrm{H}^{+}$

\section{Recent Advances in Fe-Based Remediation}

A review of the recently published literature (Scopus and Web of Science) reveals that the most notable developmental work occurring in the last 5 years has been in the field of iron nanoparticle (particularly zero-valent iron nanoparticle) remediation technologies. Over 500 related articles have been published within the last 3 years alone. Thus, despite the historical focus on the use of bulk iron minerals for sediment amendment, we focus here on the recent developments within the field of $\mathrm{Fe}$ nanoparticle amendments for improving the efficiency of waste remediation.

Although there is a lack of consensus on the definition of a nanoparticle, generally, any particle with one dimension less than $100 \mathrm{~nm}$ is regarded as being nano-particulate [161]. Iron nanoparticles may occur naturally or are produced as byproducts of other reactions. However, for remediation purposes, engineered particles are preferred as their specific properties and composition can be controlled, and their efficiency can thus be optimised [e.g. 162-164]. Depending on the properties desired, these engineered Fe nanoparticles can be produced by a variety of physical, chemical and biological methods, with co-precipitation, hydrothermal and microemulsion chemical techniques being most prevalent $[165,166]$. The choice of preparation technique can have a strong control on the resultant nanoparticle size distribution, stability, magnetism, reactivity and surface chemistry, and these properties can be further modified by the application of surface coatings [165]. A diverse array of engineered Fe nanoparticles has thus been developed, and although zerovalent $\mathrm{Fe}$ nanoparticles (and modifications thereof) are most common, other Fe minerals have also been synthesised at the nano-scale and applied to contaminant remediation studies. For example, Lin and co-workers [167] synthesised magnetic $\gamma$-FeOOH nanoparticles that adsorb $\mathrm{As}(\mathrm{III})$ and $\mathrm{As}(\mathrm{V})$ over a wide $\mathrm{pH}$ range (3-11) and cellulose-stabilised $\mathrm{FeS}$ nanoparticles have been shown to reduce $\mathrm{Hg}$ leachability by $99 \%$ [150]. Magnetite [108, 168], hematite [169], maghemite [170], hydrous iron oxide [171] and Fe phosphate nanoparticles $[158,159]$ have also all been developed and tested for their reactivity towards various contaminant phases.

Figure 4 highlights a number of factors that render these different $\mathrm{Fe}$ nano-particulate minerals more effective at contaminant breakdown and adsorption, relative to their respective bulk counterparts. In particular, $\mathrm{Fe}$ nanoparticles are characterised by a large surface area to particle size ratio (Fig. 4a), where the difference between available surface area in micro- $\left(10 \mathrm{~m}^{2} \mathrm{~kg}^{-1}\right)$ and nano- $\left(30,000 \mathrm{~m}^{2} \mathrm{~kg}^{-1}\right)$ particles is shown to be substantive [172]. Laboratory studies conducted by Waychunas and co-workers [31] have shown that the absolute uptake of bivalent metals follows the expected trend, where adsorption was highest in nanoparticles with the smallest size and largest surface area $\left(\sim 300 \mathrm{~m}^{2} \mathrm{~g}^{-1}\right)$. The reactivity of Fe nanoparticle surfaces is also much greater than observed for bulk Fe mineral surfaces (Fig. 4b). This is reflected in mathematical modelling, where Noubactep et al. [173] have shown that smaller sized zero-valent iron particles release a greater number of electrons and follow faster release kinetics (Fig. 4c) than larger sized particles, and this could enhance their effectiveness and efficiency during reductive treatment of affected sediments.

This enhanced reactivity and chemical instability can however also be a hindrance to the use of iron nanoparticles, as it affects their mobility and results in untargeted reactivity [174-177]. To overcome these issues and to increase Fe nanoparticle effectiveness, scientists modify Fe nanoparticles using other metallic elements (e.g. bimetallic nanoparticles) or by altering their surface characteristics, typically through the addition of a coating media. The performance of $\mathrm{Fe}(0)$ nanoparticles has been improved by synthesising bimetallic Fe nanoparticles, which typically exhibit better catalytic abilities in breaking down various pollutants [163]. Bimetallic nanoparticles have been synthesised with metals that have a higher redox potential than $\mathrm{Fe}$, including $\mathrm{Ag}$ [178], $\mathrm{Cu}$ [179], $\mathrm{Ni}$ $[104,121]$ and $\operatorname{Pd}[114,119,148]$. By acting as electron transfer media, these metals prevent the self-inhibitory effects associated with oxy-hydroxide precipitation on monometallic $\mathrm{Fe}(0)$ nanoparticle surfaces (Hu et al. ref 27-in Liu). Surface modification and membrane coatings can further improve the effectiveness of $\mathrm{Fe}$ nanoparticles, particularly in soil and sediment systems where they readily aggregate and where their reactivity and adsorptive behaviour can be misdirected towards the non-pollutant moieties in the soil/sediment system. Nanoparticle dispersion (and hydrophobicity), mobility and 


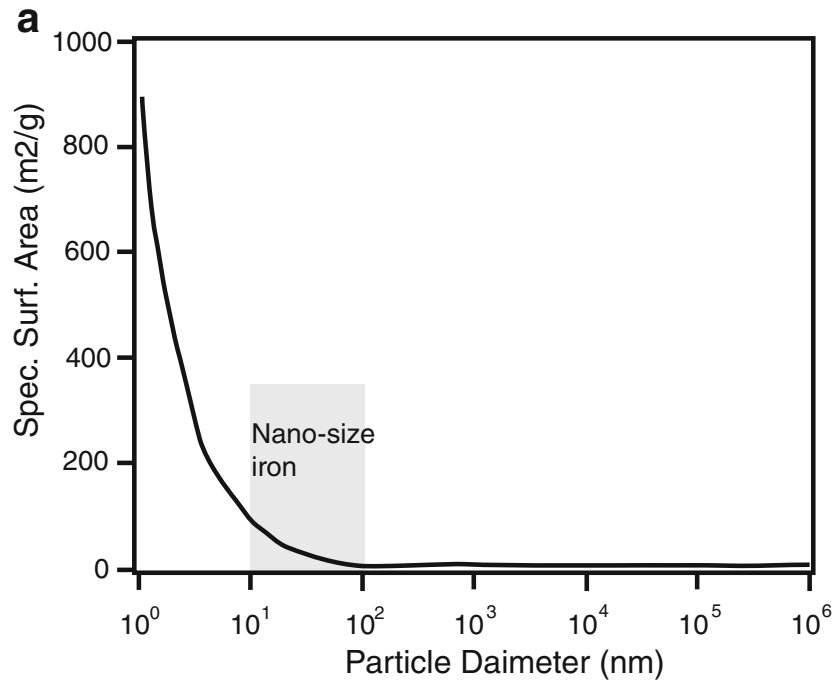

b

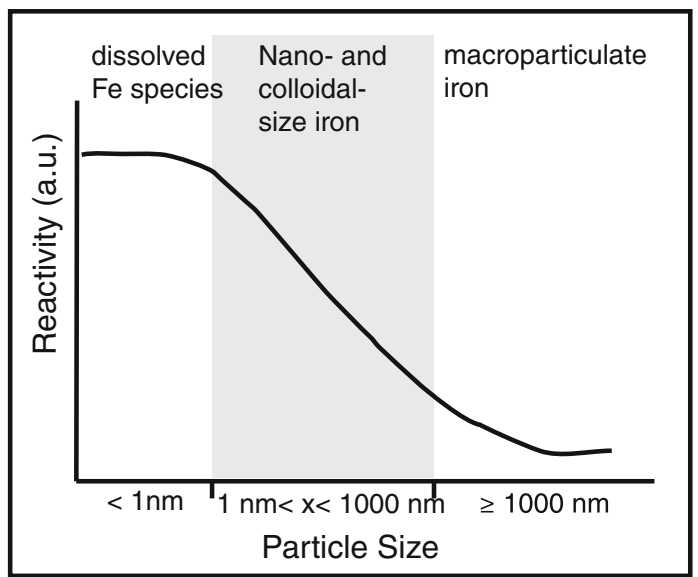

C

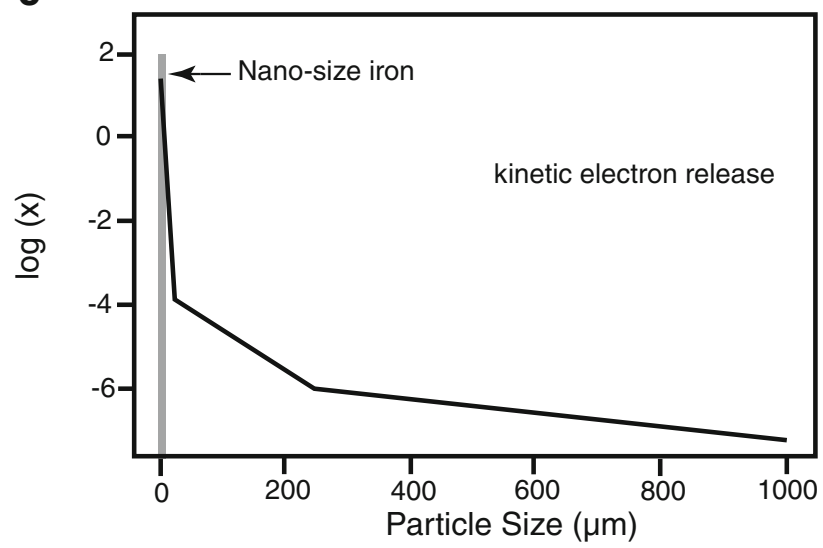

Fig. 4 Characteristics and reactivity of iron particles as a function of particle size. Change in specific surface area (based on average densities of $\mathrm{Fe}(0)$ and $\left.\mathrm{Fe}_{3} \mathrm{O}_{4}\right)$ (a), reactivity (b) and kinetic electron release (c) suggests improved capacity of nano-sized $\mathrm{Fe}$ minerals to interact with contaminants in sediments. Figure modified after [151, $172,173]$

stability have been enhanced by different organic surface modifiers including starch [102,180], cellulose [181], oils
[182] and various other anionic polymers and non-ionic surfactants [177, 183-185]. Silicon-based coatings (e.g. tetraethyl orthosilicate) can also enhance nanoparticle dispersion, and commercial applications of this technology are now available [186]. Besides increasing particle mobility, surface coatings can increase the specificity of $\mathrm{Fe}$ nanoparticle reactivity, particularly when functional groups with selective chelating ability are used [187, 188].

In summary, recent developments in Fe-based remediation of polluted sediments and soils have drawn on a fundamental understanding of the adsorptive and redox reactive properties of $\mathrm{Fe}$ and $\mathrm{Fe}$ minerals ('Iron Mineral Interactions with Sediment Pollutants' section). The advent of nanotechnology has enabled the synthesis and study of nano-sized Fe materials, which have been shown to have higher specific surface area and reactivity than their bulk counterparts (Fig. 4). As such, most developmental work has focused on the synthesis of novel Fe-based nanotechnologies for contaminant remediation. In particular, bimetallic particles and various surface modifications have been used to ensure that particles are easily mobilised in sediments (i.e. they do not aggregate easily or rapidly $[164,189,190])$; that the particles contain enough zero-valent Fe content and surface area for optimised reaction or targeted interaction with contaminants [150, 184]; and that the stabiliser characteristics do not negatively affect mobility and reactivity $[157,191,192]$. However, many of these technologies have yet to be tested in natural soil and sediment systems, where their impacts on biodegradation pathways [151] remain to be evaluated. Future work should further focus on field testing and on establishing the long-term stability and ageing of the amendment products, particularly if the amendments are to be applied as in situ treatments [e.g. 23] to sediments and soils with dynamic redox conditions.

Acknowledgments The authors would like to acknowledge three anonymous reviewers, whose inputs have greatly benefitted this manuscript. Furthermore, the National Research Foundation, South Africa is acknowledged for funding provided to AR [grant numbers: SANAP 93069, CPRR 87752]. This is AEON publication number 151 and Inkaba ye Afrika publication number 155 .

Conflict of Interest Bjorn von der Heyden and Alakendra Roychoudhury declare that they have no conflict of interest.

\section{References}

1. Pacyna JM, Pacyna EG. An assessment of global and regional emissions of trace metals to the atmosphere from anthropogenic sources worldwide. Environ Rev. 2001;9(4):269-98.

2. Torres MA, Barros MP, Campos SC, Pinto E, Rajamani S, Sayre RT, et al. Biochemical biomarkers in algae and marine pollution: a review. Ecotox Environ Safe. 2008;71(1):1-15. 
3. Akcil A, Erust C, Ozdemiroglu S, Fonti V, Beolchini F. A review of approaches and techniques used in aquatic contaminated sediments: metal removal and stabilization by chemical and biotechnological processes. J Clean Prod. 2015;86:24-36.

4. Förstner U, Apitz SE. Sediment remediation: US focus on capping and monitored natural recovery. J Soil Sediments. 2007;7(6):3518.

5. Taylor KG, Owens PN. Sediments in urban river basins: a review of sediment-contaminant dynamics in an environmental system conditioned by human activities. J Soil Sediments. 2009;9(4): 281-303.

6. Stankovic S, Jovic M. Health risks of heavy metals in the mediterranean mussels as seafood. Environ Chem Lett. 2012;10(2): 119-30.

7. Tao Y, Yuan Z, Xiaon H, Wei M. Distribution and bioaccumulation of heavy metals in aquatic organisms of different trophic levels and potential health risk assessment from Taihu lake, China. Ecotox Environ Saf. 2012;81:55-64.

8. Karadede-Akin H, Ünlü E. Heavy metal concentrations in water, sediment, fish and some benthic organisms from Tigris River, Turkey. Environ Monit Assess. 2007;131(1-3):323-37.

9. Saifullah $\mathrm{SM}$, Ismail $\mathrm{S}$, Khan $\mathrm{SH}$, Saleem M. Land use-iron pollution in Mangrove Habitat of Karachi, Indus Delta. Earth Interact. 2004;8(17):1-9.

10. Sahrawat KL. Iron toxicity in wetland rice and the role of other nutrients. J Plant Nutr. 2005;27(8):1471-504.

11. Stein RJ, Duarte GL, Spohr MG, Lopes SIG, Fett JP. Distinct physiological responses of two rice cultivars subjected to iron toxicity under field conditions. Ann Appl Biol. 2009;154(2): 269-77.

12. Cornell RM, Schwertmann U. The iron oxides: structure, properties, reactions, occurrences and uses. John Wiley \& Sons. 2006.

13. Figueroa RA, MacKay AA. Sorption of oxytetracycline to iron oxides and iron oxide-rich soils. Environ Sci Technol. 2005;39(17):6664-71.

14. Qin X, Liu F, Wang G, Li L, Wang Y, Weng L. Modeling of levofloxacin adsorption to goethite and the competition with phosphate. Chemosphere. 2014;111:283-90.

15. Sherman DM, Randall SR. Surface complexation of arsenic (V) to iron (III)(hydr) oxides: structural mechanism from ab initio molecular geometries and EXAFS spectroscopy. Geochim Cosmochim Acta. 2003;67(22):4223-30.

16. Spadini L, Manceau A, Schindler PW, Charlet L. Structure and stability of Cd 2+ surface complexes on ferric oxides: 1 . Results from EXAFS spectroscopy. J Colloid Interface Sci. 1994;168(1): $73-86$.

17. Yuan T, Hu JY, Ong SL, Luo QF, Ng WJ. Arsenic removal from household drinking water by adsorption. J Environ Sci Health A. 2002;37:1721-36.

18. Cundy AB, Hopkinson L, Whitby RL. Use of iron-based technologies in contaminated land and groundwater remediation: a review. Sci Total Environ. 2008;400(1):42-51.

19. Komárek M, Vaněk A, Ettler V. Chemical stabilization of metals and arsenic in contaminated soils using oxides - a review. Environ Pollut. 2013;172:9-22.

20. Kumpiene J, Lagerkvist A, Maurice C. Stabilization of $\mathrm{As}, \mathrm{Cr}, \mathrm{Cu}$, $\mathrm{Pb}$ and $\mathrm{Zn}$ in soil using amendments - a review. Waste Manag. 2008;28(1):215-25.

21. Chiang YW, Santos RM, Ghyselbrecht K, Cappuyns V, Martens JA, Swennen R, et al. Strategic selection of an optimal sorbent mixture for in-situ remediation of heavy metal contaminated sediments: framework and case study. J Environ Manag. 2012;105:111.

22. Peng JF, Song YH, Yuan P, Cui XY, Qiu GL. The remediation of heavy metals contaminated sediment. J Hazard Mater. 2009;161(2):633-40.
23. Qian G, Chen W, Lim TT, Chui P. In-situ stabilization of Pb, Zn, $\mathrm{Cu}, \mathrm{Cd}$ and $\mathrm{Ni}$ in the multi-contaminated sediments with ferrihydrite and apatite composite additives. J Hazard Mater. 2009;170(2):1093-100.

24. Mamindy-Pajany Y, Hurel C, Geret F, Roméo M, Marmier N. Comparison of mineral-based amendments for ex-situ stabilization of trace elements ( $\mathrm{As}, \mathrm{Cd}, \mathrm{Cu}, \mathrm{Mo}, \mathrm{Ni}, \mathrm{Zn}$ ) in marine dredged sediments: a pilot-scale experiment. J Hazard Mater. 2013;252: 213-9.

25. Fredette TJ. Why confined aquatic disposal cells often make sense. Integr Environ Assess Manag. 2006;2(1):35-8.

26. Mamindy-Pajany Y, Galgani F, Roméo M, Hurel C, Marmier N. Minerals as additives for decreasing the toxicity of Mediterranean contaminated dredged sediments. Ecotox Environ Safe. 2010;73(7):1748-54.

27. Schwertmann U, Fitzpatrick RW. Occurrence of lepidocrocite and its association with goethite in Natal soils. Soil Sci Soc Am J. 1977;41(5):1013-8.

28. Bibi I, Singh B, Silvester E. Akaganéite $(\beta-\mathrm{FeOOH})$ precipitation in inland acid sulfate soils of south-western New South Wales (NSW), Australia. Geochim Cosmochim Acta. 2011;75(21): 6429-38.

29. Karathanasis AD, Thompson YL. Mineralogy of iron precipitates in a constructed acid mine drainage wetland. Soil Sci Soc Am J. 1995;59(6):1773-81.

30. Stumm W. Morgan J.J. Aquatic chemistry: chemical equilibria and rates in natural waters (Vol. 126). John Wiley \& Sons. 2012.

31. Waychunas GA, Kim CS, Banfield JF. Nanoparticulate iron oxide minerals in soils and sediments: unique properties and contaminant scavenging mechanisms. J Nano Res. 2005;7(4-5):409-33.

32. Hayes KF, Leckie JO. Modelling ionic strength effects on cation sorption at hydrous oxide/solution interfaces. J Colloid Interface Sci. 1987;115:564-72.

33. Manceau A, Charlet L. The mechanism of selenite adsorption on goethite and hydrous ferric oxide. J Colloid Interface Sci. 1994;168:87-93.

34. Martinez CE, McBride MB. Coprecipitates of $\mathrm{Cd}, \mathrm{Cu}, \mathrm{Pb}$ and $\mathrm{Zn}$ in iron oxides: solid phase transformation and metal solubility after aging and thermal treatment. Clays Clay Miner. 1998;46(5):537-45.

35. Borch T, Kretzschmar R, Kappler A, Cappellen PV, Ginder-Vogel $\mathrm{M}$, Voegelin A, et al. Biogeochemical redox processes and their impact on contaminant dynamics. Environ Sci Technol. 2009;44(1):15-23.

36. Rickard D, Luther GW. Chemistry of iron sulfides. Chem Rev. 2007;107(2):514-62.

37. Rickard D, Morse JW. Acid volatile sulfide (AVS). Mar Chem. 2005;97(3):141-97.

38. Suess E, Wallschläger D, Planer-Friedrich B. Stabilization of thioarsenates in iron-rich waters. Chemosphere. 2011;83(11): 1524-31.

39. Argos M, Kalra T, Rathouz PJ, Chen Y, Pierce B, Parvez F, et al. Arsenic exposure from drinking water, and all-cause and chronicdisease mortalities in Bangladesh (HEALS): a prospective cohort study. Lancet. 2010;376(9737):252-8.

40. Manning BA, Fendorf SE, Bostick B, Suarez DL. Arsenic (III) oxidation and arsenic (V) adsorption reactions on synthetic birnessite. Environ Sci Technol. 2002;36(5):976-81.

41. Caussy D. Case studies of the impact of understanding bioavailability: arsenic. Ecotox Environ Safe. 2003;56(1):164-73.

42. Jain A, Raven KP, Loeppert RH. Arsenite and arsenate adsorption on ferrihydrite: surface charge reduction and net $\mathrm{OH}$-release stoichiometry. Environ Sci Technol. 1999;33(8):1179-84.

43. Mohan D, Pittman Jr CU. Arsenic removal from water/wastewater using adsorbents — a critical review. J Hazard Mater. 2007;142:1 53. 
44. Masue Y, Loeppert RH, Kramer TA. Arsenate and arsenite adsorption and desorption behavior on coprecipitated aluminum: iron hydroxides. Environ Sci Technol. 2007;41(3):837-42.

45. Redman AD, Macalady DL, Ahmann D. Natural organic matter affects arsenic speciation and sorption onto hematite. Environ Sci Technol. 2002;36(13):2889-96.

46. Zhu J, Pigna M, Cozzolino V, Caporale AG, Violante A. Sorption of arsenite and arsenate on ferrihydrite: effect of organic and inorganic ligands. J Hazard Mater. 2011;189(1):564-71.

47. Gräfe M, Nachtegaal M, Sparks DL. Formation of metal-arsenate precipitates at the goethite-water interface. Environ Sci Technol. 2004;38(24):6561-70.

48. Atkinson CA, Jolley DF, Simpson SL. Effect of overlying water $\mathrm{pH}$, dissolved oxygen, salinity and sediment disturbances on metal release and sequestration from metal contaminated marine sediments. Chemosphere. 2007;69(9):1428-37.

49. Gerringa LJA. Aerobic degradation of organic matter and the mobility of $\mathrm{Cu}, \mathrm{Cd}, \mathrm{Ni}, \mathrm{Pb}, \mathrm{Zn}, \mathrm{Fe}$ and $\mathrm{Mn}$ in marine sediment slurries. Mar Chem. 1990;29:355-74.

50. Mohan D, Pittman CU. Activated carbons and low cost adsorbents for remediation of tri-and hexavalent chromium from water. $\mathrm{J}$ Hazard Mater. 2006;137(2):762-811.

51. Fendorf SE. Surface reactions of chromium in soils and waters. Geoderma. 1995;67(1):55-71.

52. Døssing LN, Dideriksen K, Stipp SLS, Frei R. Reduction of hexavalent chromium by ferrous iron: a process of chromium isotope fractionation and its relevance to natural environments. Chem Geol. 2011;285(1):157-66.

53. Buerge IJ, Hug SJ. Influence of organic ligands on chromium (VI) reduction by iron (II). Environ Sci Technol. 1998;32(14):2092-9.

54. Fendorf SE, Zasoski RJ. Chromium (III) oxidation by. delta.-manganese oxide (MnO2). 1. Characterization. Environ Sci Technol. 1992;26(1):79-85.

55. Violante A, Ricciardella M, Pigna M, Capasso R. Effects of organic ligands on the adsorption of trace elements onto metal oxides and organo-mineral complexes. Biogeochemistry of trace elements in the rhizosphere $2005 ; 157-182$.

56. Trivedi P, Axe L, Tyson TA. An analysis of zinc sorption to amorphous versus crystalline iron oxides using XAS. J Colloid Interface Sci. 2001;244(2):230-8.

57. Waychunas GA, Fuller CC, Davis JA. Surface complexation and precipitate geometry for aqueous $\mathrm{Zn}$ (II) sorption on ferrihydrite I: $\mathrm{X}$-ray absorption extended fine structure spectroscopy analysis. Geochim Cosmochim Acta. 2002;66(7):1119-37.

58. Bargar JR, Brown GE, Parks GA. Surface complexation of Pb (II) at oxide-water interfaces: II. XAFS and bond-valence determination of mononuclear $\mathrm{Pb}$ (II) sorption products and surface functional groups on iron oxides. Geochim Cosmochim Acta. 1997;61(13):2639-52.

59. Manceau A, Charlet L, Boisset MC, Didier B, Spadini L. Sorption and speciation of heavy metals on hydrous Fe and Mn oxides. From microscopic to macroscopic. Appl Clay Sci. 1992;7(1): 201-23.

60. Dong D, Nelson YM, Lion LW, Shuler ML, Ghiorse WC. Adsorption of $\mathrm{Pb}$ and $\mathrm{Cd}$ onto metal oxides and organic material in natural surface coatings as determined by selective extractions: new evidence for the importance of $\mathrm{Mn}$ and Fe oxides. Water Res. 2000;34(2):427-36.

61. McKenzie RM. The adsorption of lead and other heavy metals on oxides of manganese and iron. Soil Res. 1980;18(1):61-73.

62. Wagai R, Mayer LM. Sorptive stabilization of organic matter in soils by hydrous iron oxides. Geochim Cosmochim Acta. 2007;71(1):25-35.

63. Lalonde K, Mucci A, Ouellet A, Gélinas Y. Preservation of organic matter in sediments promoted by iron. Nature. 2012;483(7388): 198-200.
64. von der Heyden BP, Hauser EJ, Mishra B, Martinez GA, Bowie $\mathrm{AR}$, Tyliszczak T, et al. Ubiquitous presence of $\mathrm{Fe}$ (II) in aquatic colloids and its association with organic carbon. Environ Sci Technol Lett. 2014;1(10):387-92.

65. Guo X, Yang C, Dang Z, Zhang Q, Li Y, Meng Q. Sorption thermodynamics and kinetics properties of tylosin and sulfamethazine on goethite. Chem Eng J. 2013;223:59-67.

66. Gu C, Karthikeyan KG. Interaction of tetracycline with aluminum and iron hydrous oxides. Environ Sci Technol. 2005;39(8):2660 7.

67. Matta R, Hanna K, Chiron S. Fenton-like oxidation of 2, 4, 6trinitrotoluene using different iron minerals. Sci Total Environ. 2007;385(1):242-51.

68. Watts RJ, Udell MD, Kong S, Leung SW. Fenton-like soil remediation catalyzed by naturally occurring iron minerals. Environ Eng Sci. 1999;16(1):93-103.

69. Davranche M, Bollinger JC. Heavy metals desorption from synthesized and natural iron and manganese oxyhydroxides: effect of reductive conditions. J Colloid Interface Sci. 2000;227(2):531-9.

70. Pedersen HD, Postma D, Jakobsen R. Release of arsenic associated with the reduction and transformation of iron oxides. Geochim Cosmochim Acta. 2006;70(16):4116-29.

71. Yamaguchi N, Nakamura T, Dong D, Takahashi Y, Amachi S, Makino T. Arsenic release from flooded paddy soils is influenced by speciation, Eh, $\mathrm{pH}$, and iron dissolution. Chemosphere. 2011;83(7):925-32.

72. Lee G, Bigham JM, Faure G. Removal of trace metals by coprecipitation with $\mathrm{Fe}, \mathrm{Al}$ and $\mathrm{Mn}$ from natural waters contaminated with acid mine drainage in the Ducktown Mining District, Tennessee. Appl Geochem. 2002;17(5):569-81.

73. Moore TJ, Rightmire CM, Vempati RK. Ferrous iron treatment of soils contaminated with arsenic-containing wood-preserving solution. Soil Sediment Contam. 2000;9:375-405.

74. Warren GP, Alloway BJ, Lepp NW, Singh B, Bochereau FJM, Penny C. Field trials to assess the uptake of arsenic by vegetables from contaminated soils and soil remediation with iron oxides. Sci Total Environ. 2003;311:19-33.

75. Warren GP, Alloway BJ. Reduction of arsenic uptake by lettuce with ferrous sulfate applied to contaminated soil. J Environ Qual. 2003;32:767-72.

76. Hartley W, Lepp NW. Effect of in situ soil amendments on arsenic uptake in successive harvests of ryegrass (Lolium perenne cv Elka) grown in amended As-polluted soils. Environ Pollut. 2008; 156:1030-40.

77. García-Sanchez A, Alvarez-Ayuso E, Rodriguez-Martin F. Sorption of $\mathrm{As}(\mathrm{V})$ by some oxyhydroxides and clay minerals. Application to its immobilization in two polluted soils. Clay Miner. 2002;37:187-94.

78. Gonzalez V, Garcia I, Del Moral F, Simón M. Effectiveness of amendments on the spread and phytotoxicity of contaminants in metal-arsenic polluted soil. J Hazard Mater. 2012;205-206:72-80.

79. Bleeker PM, Assunção AGL, Teiga PM, de Koe T, Verkleij JAC. Revegetation of the acidic, As contaminated Jales mine spoil tips using a combination of spoil amendments and tolerant grasses. Sci Total Environ. 2002;300:1-13.

80. Lien HL, Wilkin RT. High-level arsenite removal from groundwater by zerovalent iron. Chemosphere. 2005;59:377.

81. Hartley W, Edwards R, Lepp NW. Arsenic and heavy metal mobility in iron oxide-amended contaminated soils as evaluated by short-and long-term leaching tests. Environ Pollut. 2004;131(3): 495-504.

82. Nikolaidis NP, Dobbs GM, Lackovic JA. Arsenic removal by zero-valent iron: field, laboratory and modeling studies. Water Res. 2003;37:1417-25.

83. Su CM, Puls RW. Arsenate and arsenite removal by zerovalent iron: kinetics, redox transformation, and implications for in situ 
groundwater remediation. Environ Sci Technol. 2001;35:148792.

84. Ramos MAV, Yan W, Li XQ, Koel BE, Zhang WX. Simultaneous oxidation and reduction of arsenic by zero-valent iron nanoparticles: understanding the significance of the core-shell structure. J Phys Chem C. 2009;113:14591-4.

85. Kumpiene J, Ore S, Renella G, Mench M, Lagerkvist A, Maurice C. Assessment of zerovalent iron for stabilization of chromium, copper, and arsenic in soil. Environ Pollut. 2006;144(1):62-9.

86. Friesl W, Friedl J, Platzer K, Horak O, Gerzabek MH. Remediation of contaminated agricultural soils near a former $\mathrm{Pb} / \mathrm{Zn}$ smelter in Austria: batch, pot and field experiments. Environ Pollut. 2006;144:40-50.

87. Mench M, Vangronsveld J, Beck C, Ruttens A. Progress in assisted natural remediation of an arsenic contaminated agricultural soil. Environ Pollut. 2006;144:51-61.

88. Boparai HK, Joseph M, O'Carroll DM. Kinetics and thermodynamics of cadmium ion removal by adsorption onto nanozerovalent iron particles. J Hazard Mater. 2011;186:458-65.

89. Lee SH, Park H, Koo N, Hyun S, Hwang A. Evaluation of the effectiveness of various amendments on trace metals stabilization by chemical and biological methods. J Hazard Mater. 2011;188: 44-51.

90. Hanauer T, Felix-Henningsen P, Steffens D, Kalandadze B, Navrozashvili L, Urushadze T. In situ stabilization of metals $(\mathrm{Cu}, \mathrm{Cd}$, and $\mathrm{Zn})$ in contaminated soils in the region of Bolnisi, Georgia. Plant Soil. 2011;341:193-208.

91. Chen HM, Zheng CR, Tu C, Shen ZG. Chemical methods and phytoremediation of soil contaminated with heavy metals. Chemosphere. 2000;41:229-34.

92. Lombi E, Zhao FJ, Zhang GY, Sun B, Fitz W, Zhang H, et al. In situ fixation of metals in soils using bauxite residue: chemical assessment. Environ Pollut. 2002;118:435-43.

93. Lombi E, Zhao FJ, Wieshammer G, Zhang GY, McGrath SP. In situ fixation of metals in soils using bauxite residue: biological effects. Environ Pollut. 2002;118:445-52.

94. Friesl W, Lombi E, Horak O, Wenzel WW. Immobilization of heavy metals in soils using inorganic amendments in a greenhouse study. J Plant Nutr Soil Sci. 2003;166:191-6.

95. Gray CW, Dunham SJ, Dennis PG, Zhao FJ, McGrath SP. Field evaluation of in situ remediation of a heavy metal contaminated soil using lime and redmud. Environ Pollut. 2006;142:530-9.

96. McBride MB, Martínez CE. Copper phytotoxicity in a contaminated soil: remediation tests with adsorptive materials. Environ Sci Technol. 2000;34:4386-91.

97. Lombi E, Hamon RE, McGrath SP, McLaughlin MJ. Lability of $\mathrm{Cd}, \mathrm{Cu}$, and $\mathrm{Zn}$ in polluted soils treated with lime, beringite, and red mud and identification of a non-labile colloidal fraction of metals using isotopic techniques. Environ Sci Technol. 2003;37: 979-84.

98. Kumpiene J, Mench M, Bes CM, Fitts JP. Assessment of aided phytostabilization of copper-contaminated soil by X-ray absorption spectroscopy and chemical extractions. Environ Pollut. 2011;159:1536-42.

99. Bes C, Mench M. Remediation of copper-contaminated topsoils from a wood treatment facility using in situ stabilization. Environ Pollut. 2008;156:1128-38.

100. Li XQ, Cao JS, Zhang WX. Stoichiometry of Cr(VI) immobilization using nanoscale zerovalent iron (nZVI): a study with highresolution X-ray photoelectron Spectroscopy (HR-XPS). Ind Eng Chem Res. 2008;47:2131-9.

101. Hoch LB, Mack EJ, Hydutsky BW, Hershman JM, Skluzacek JM, Mallouk TE. Carbothermal synthesis of carbon-supported nanoscale zero-valent iron particles for the remediation of hexavalent chromium. Environ Sci Technol. 2008;42:2600-5.
102. Rivero-Huguet M, Marshall WD. Reduction of hexavalent chromium mediated by micron- and nano-scale zero-valent metallic particles. J Environ Monit. 2009;11:1072-9.

103. Scheinost AC, Kirsch R, Banerjee D, Fernandez-Martinez A, Zaenker $\mathrm{H}$, Funke $\mathrm{H}$, et al. X-ray absorption and photoelectron spectroscopy investigation of selenite reduction by Fe(II)-bearing minerals. J Contam Hydrol. 2008;102:228-45.

104. Mondal K, Jegadeesan G, Lalvani SB. Removal of selenate by Fe and NiFe nanosized particles. Ind Eng Chem Res. 2004;43:492234.

105. Olegario JT, Yee N, Miller M, Sczepaniak J, Manning B. Reduction of $\mathrm{Se}(\mathrm{VI})$ to $\mathrm{Se}(-\mathrm{II})$ by zerovalent iron nanoparticle suspensions. J Nano Res. 2010;12:2057-68.

106. Dickinson M, Scott TB. The application of zero-valent iron nanoparticles for the remediation of a uranium-contaminated waste effluent. J Hazard Mater. 2010;178:171-9.

107. Yan S, Hua B, Bao ZY, Yang J, Liu CX, Deng BL. Uranium(VI) removal by nanoscale zerovalent iron in anoxic batch systems. Environ Sci Technol. 2010;44:7783-9.

108. Crane RA, Dickinson M, Popescu IC, Scott TB. Magnetite and zero-valent iron nanoparticles for the remediation of uranium contaminated environmental water. Water Res. 2011;45:2931-42.

109. Satapanajaru T, Anurakpongsatorn P, Pengthamkeerati P, Boparai $H$. Remediation of atrazine-contaminated soil and water by nano zerovalent iron. Water Air Soil Pollut. 2008;192:349-59.

110. Matheson LJ, Tratnyek PG. Reductive dehalogenation of chlorinated methanes by iron metal. Environ Sci Technol. 1994;28: 2045.

111. Lien H-L, Zhang W-X. Transformation of chlorinated methanes by nanoscale iron particles. J Environ Eng-ASCE. 1999;125: 1042-7.

112. Danielsen KM, Hayes KF. pH dependence of carbon tetrachloride reductive dechlorination by magnetite. Environ Sci Technol. 2004;38:4745-52.

113. Song H, Carraway ER. Reduction of chlorinated ethanes by nanosized zerovalent iron: kinetics, pathways, and effects of reaction conditions. Environ Sci Technol. 2005;39:6237-45.

114. Lien HL, Zhang WX. Hydrodechlorination of chlorinated ethanes by nanoscale $\mathrm{Pd} / \mathrm{Fe}$ bimetallic particles. J Environ Eng-ASCE. 2005;131:4-10.

115. Orth WS, Gillham RW. Dechlorination of trichloroethene in aqueous solution using Fe-O. Environ Sci Technol. 1996;30:66-71.

116. Farrell J, Kason M, Melitas N, Li T. Investigation of the long-term performance of zero-valent iron for reductive dechlorination of trichloroethylene. Environ Sci Technol. 2000;34:514-21.

117. Su C, Puls RW. Kinetics of trichloroethene reduction by zerovalent iron and tin: pretreatment effect, apparent activation energy, and intermediate products. Environ Sci Technol. 1999;33:163-8.

118. Liu Y, Choi H, Dionysiou D, Lowry GV. Trichloroethene hydrodechlorination in water by highly disordered monometallic nanoiron. Chem Mater. 2005;17:5315-22.

119. He F, Zhao DY. Hydrodechlorination of trichloroethene using stabilized Fe-Pd nanoparticles: reaction mechanism and effects of stabilizers, catalysts and reaction conditions. Appl Catal BEnviron. 2008;84:533-40.

120. Barnes RJ, Riba O, Gardner MN, Scott TB, Jackman SA, Thompson IP. Optimization of nano-scale nickel/iron particles for the reduction of high concentration chlorinated aliphatic hydrocarbon solutions. Chemosphere. 2010;79:448-54.

121. Schrick B, Blough JL, Jones AD, Mallouk TE. Hydrodechlorination of trichloroethylene to hydrocarbons using bimetallic nickel-iron nanoparticles. Chem Mater. 2002;14: 5140-7.

122. Kim HS, Kang WH, Kim M, Park JY, Hwang I. Comparison of hematite/Fe(II) systems with cement/Fe(II) systems in reductively dechlorinating trichloroethylene. Chemosphere. 2008;73:813-9. 
123. Zheng TH, Zhan JJ, He JB, Day C, Lu YF, Mcpherson GL, et al. Reactivity characteristics of nanoscale zerovalent iron-silica composites for trichloroethylene remediation. Environ Sci Technol. 2008;42:4494-9.

124. Baciocchi R, Boni MR, D'Aprile L. Characterization and performance of granular iron as reactive media for TCE degradation by permeable reactive barriers. Water Air Soil Pollut. 2003;149:21126.

125. Zhu NR, Luan HW, Yuan SH, Chen J, Wu XH, Wang LL. Effective dechlorination of $\mathrm{HCB}$ by nanoscale $\mathrm{Cu} / \mathrm{Fe}$ particles. J Hazard Mater. 2010;176:1101-5.

126. Chuang FW, Larson RA, Wessman MS. Zero-valent iron-promoted dechlorination of polychlorinated-biphenyls. Environ Sci Technol. 1995;29:2460-3.

127. Wang Y, Zhou D, Wang Y, Zhu X, Jin S. Humic acid and metal ions accelerating the dechlorination of 4-chlorobiphenyl by nanoscale zero-valent iron. J Environ Sci. 2011;23:1286-92.

128. Grittini C, Malcomson M, Fernando Q, Korte N. Rapid dechlorination of polychlorinated biphenyls on the surface of a $\mathrm{Pd} / \mathrm{Fe}$ bimetallic system. Environ Sci Technol. 1995;29:2898-900.

129. Zhu BW, Lim TT. Catalytic reduction of chlorobenzenes with $\mathrm{Pd} /$ Fe nanoparticles: reactive sites, catalyst stability, particle aging, and regeneration. Environ Sci Technol. 2007;41:7523-9.

130. Satapanajaru T, Anurakpongsatorn P, Songsasen A, Boparai H, Park J. Using low-cost iron byproducts from automotive manufacturing to remediate DDT. Water Air Soil Pollut. 2006;175:361-74.

131. Quinn J, Geiger C, Clausen C, Brooks K, Coon C, O'Hara S, et al. Field demonstration of DNAPL dehalogenation using emulsified zero-valent iron. Environ Sci Technol. 2005;39:1309-18.

132. Agrawal A, Tratnyek PG. Reduction of nitro aromatic compounds by zerovalent iron metal. Environ Sci Technol. 1996;30:153-60.

133. Hundal LS, Singh J, Bier EL, Shea PJ, Comfort SD, Powers WL. Removal of TNT and RDX from water and soil using iron metal. Environ Pollut. 1997;97:55-64.

134. Bandstra JZ, Miehr R, Johnson RL, Tratnyek PG. Reduction of 2, 4,6-trinitrotoluene by iron metal: kinetic controls on product distributions in batch experiments. Environ Sci Technol. 2005;39: $230-8$.

135. Loyaux-Lawniczak S, Lecomte P, Ehrhardt JJ. Behavior of hexavalent chromium in a polluted groundwater: redox processes and immobilization in soils. Environ Sci Technol. 2001;35(7): 1350-7.

136. Matocha CJ, Karathanasis AD, Rakshit S, Wagner KM. Reduction of copper (II) by iron (II). J Environ Qual. 2005;34(5):1539-46.

137. Genovese A, Mellini M. Ferrihydrite flocs, native copper nanocrystals and spontaneous remediation in the Fosso dei Noni stream, Tuscany, Italy. Appl Geochem. 2007;22(7):1439-50.

138. Gorny J, Billon G, Lesven L, Dumoulin D, Madé B, Noiriel C. Arsenic behavior in river sediments under redox gradient: a review. Sci Total Environ. 2015;505:423-34.

139. Amstaetter K, Borch T, Larese-Casanova P, Kappler A. Redox transformation of arsenic by $\mathrm{Fe}$ (II)-activated goethite $(\alpha$ FeOOH). Environ Sci Technol. 2009;44(1):102-8.

140. Ona-Nguema G, Morin G, Wang Y, Foster AL, Juillot F, Calas G, et al. XANES evidence for rapid arsenic (III) oxidation at magnetite and ferrihydrite surfaces by dissolved $\mathrm{O} 2$ via $\mathrm{Fe} 2+$-mediated reactions. Environ Sci Technol. 2010;44(14):5416-22.

141. Stipp SLS, Hansen M, Kristensen R, Hochella MF, Bennedsen L, Dideriksen K, et al. Behaviour of Fe-oxides relevant to contaminant uptake in the environment. Chem Geol. 2002;190(1):321-37.

142. Carbone C, Dinelli E, Marescotti P, Gasparotto G, Lucchetti G. The role of AMD secondary minerals in controlling environmental pollution: indications from bulk leaching tests. J Geochem Explor. 2013;132:188-200
143. Morse JW, Luther GW. Chemical influences on trace metal-sulfide interactions in anoxic sediments. Geochim Cosmochim Acta. 1999;63(19):3373-8.

144. Weber FA, Voegelin A, Kretzschmar R. Multi-metal contaminant dynamics in temporarily flooded soil under sulfate limitation. Geochim Cosmochim Acta. 2009;73(19):5513-27.

145. Pósfai M, Buseck PR, Bazylinski DA, Frankel RB. Reaction sequence of iron sulfide minerals in bacteria and their use as biomarkers. Science. 1998;280(5365):880-3.

146. Qafoku NP, Kukkadapu RK, McKinley JP, Arey BW, Kelly SD, Wang C, et al. Uranium in framboidal pyrite from a naturally bioreduced alluvial sediment. Environ Sci Technol. 2009;43(22): 8528-34.

147. Sun F. Arsenic chemistry with sulfide, pyrite, zero-valent iron, and magnetite (Doctoral dissertation, The Pennsylvania State University). 2010.

148. Chen X, Yao X, Yu C, Su X, Shen C, Chen C, et al. Hydrodechlorination of polychlorinated biphenyls in contaminated soil from an e-waste recycling area, using nanoscale zerovalent iron and $\mathrm{Pd} / \mathrm{Fe}$ bimetallic nanoparticles. Environ Sci Pollut Res. 2014;21(7):5201-10.

149. Sun Y, Ding C, Cheng W, Wang X. Simultaneous adsorption and reduction of $\mathrm{U}(\mathrm{VI})$ on reduced graphene oxide-supported nanoscale zerovalent iron. J Hazard Mater. 2014;280:399-408.

150. Xiong Z, He F, Zhao D, Barnett MO. Immobilization of mercury in sediment using stabilized iron sulfide nanoparticles. Water Res. 2009;43(20):5171-9.

151. Braunschweig J, Bosch J, Meckenstock RU. Iron oxide nanoparticles in geomicrobiology: from biogeochemistry to bioremediation. N Biotechnol. 2013;30(6):793-802.

152. Schroth AW, Parnell Jr RA. Trace metal retention through the schwertmannite to goethite transformation as observed in a field setting, Alta Mine, MT. Appl Geochem. 2005;20:907-17.

153. Frierdich AJ, Luo Y, Catalano JG. Trace element cycling through iron oxide minerals during redox-driven dynamic recrystallization. Geology. 2011;39(11):1083-6.

154. Liu R, Lal R. Nanoenhanced materials for reclamation of mine lands and other degraded soils: a review. J Nanotech. 2012.

155. Li XQ, Elliott DW, Zhang WX. Zero-valent iron nanoparticles for abatement of environmental pollutants: materials and engineering aspects. Crc Cr Rev Sol State. 2006;31(4):111-22.

156. Villa RD, Trovó AG, Nogueira RFP. Environmental implications of soil remediation using the Fenton process. Chemosphere. 2008;71(1):43-50

157. O'Carroll D, Sleep B, Krol M, Boparai H, Kocur C. Nanoscale zero valent iron and bimetallic particles for contaminated site remediation. Adv Water Resour. 2013;51:104-22.

158. Liu R, Zhao D. In situ immobilization of $\mathrm{Cu}$ (II) in soils using a new class of iron phosphate nanoparticles. Chemosphere. 2007;68(10):1867-76.

159. Rouvimov S, Adam N, Gates J, Beachel B. Copper (II) remediation using novel iron-phosphate nanoparticles. Microsc Microanal. 2013;19(S2):2004-5.

160. Di Palma L, Gueye MT, Petrucci E. Hexavalent chromium reduction in contaminated soil: a comparison between ferrous sulphate and nanoscale zero-valent iron. J Hazard Mater. 2015;281:70-6.

161. Klaine SJ, Alvarez PJ, Batley GE, Fernandes TF, Handy RD, Lyon DY. Nanomaterials in the environment: behavior, fate, bioavailability, and effects. Environ Toxicol Chem. 2008;27(9):1825-51.

162. Bhaumik M, Choi HJ, McCrindle RI, Maity A. Composite nanofibers prepared from metallic iron nanoparticles and polyaniline: high performance for water treatment applications. J Colloid Interface Sci. 2014;425:75-82.

163. Liu WJ, Qian TT, Jiang H. Bimetallic Fe nanoparticles: recent advances in synthesis and application in catalytic elimination of environmental pollutants. Chem Eng J. 2014;236:448-63. 
164. Sun YP, Li XQ, Zhang WX, Wang HP. A method for the preparation of stable dispersion of zero-valent iron nanoparticles. Colloids Surf A. 2007;308(1):60-6.

165. Xu P, Zeng GM, Huang DL, Feng CL, Hu S, Zhao MH, et al. Use of iron oxide nanomaterials in wastewater treatment: a review. Sci Total Environ. 2012;424:1-10.

166. Mahmoudi M, Sant S, Wang B, Laurent S, Sen T. Superparamagnetic iron oxide nanoparticles (SPIONs): development, surface modification and applications in chemotherapy. Adv Drug Deliv Rev. 2011;63:24-46.

167. Lin S, Lu D, Liu Z. Removal of arsenic contaminants with magnetic $\gamma$-Fe2O3 nanoparticles. Chem Eng J. 2012;211-212:46-52.

168. Ozmen M, Can K, Arslan G, Tor A, Cengeloglu Y, Ersoz M. Adsorption of $\mathrm{Cu}$ (II) from aqueous solution by using modified Fe3O4 magnetic nanoparticles. Desalination. 2010;254:162-9.

169. He YT, Wan J, Tokunaga T. Kinetic stability of hematite nanoparticles: the effect of particle sizes. J Nano Res. 2008;10(2):321-32.

170. Martínez-Fernández D, Vítková M, Bernal MP, Komárek M. Effects of nano-maghemite on trace element accumulation and drought response of helianthus annuus 1 . in a contaminated mine soil. Water Air Soil Pollut. 2015;226(4):1-9.

171. Sylvester P, Westerhoff P, Möller T, Badruzzaman M, Boyd O. A hybrid sorbent utilizing nanoparticles of hydrous iron oxide for arsenic removal from drinking water. Environ Eng Sci. 2007;24(1):104-12.

172. Keane E. Fate, transport, and toxicity of nanoscale zero-valent iron (nZVI) used during superfund remediation. US Environmental Protection Agency. 2009.

173. Noubactep C, Caré S, Crane R. Nanoscale metallic iron for environmental remediation: prospects and limitations. Water Air Soil Pollut. 2012;223(3):1363-82.

174. Comba S, Di Molfetta A, Sethi R. A comparison between field applications of nano-, micro-, and millimetric zero-valent iron for the remediation of contaminated aquifers. Water Air Soil Pollut. 2011;215(1-4):595-607.

175. Phenrat T, Saleh N, Sirk K, Tilton RD, Lowry GV. Aggregation and sedimentation of aqueous nanoscale zerovalent iron dispersions. Environ Sci Technol. 2007;41(1):284-90.

176. Saleh N, Sirk K, Liu Y, Phenrat T, Dufour B, Matyjaszewski K, et al. Surface modifications enhance nanoiron transport and NAPL targeting in saturated porous media. Environ Eng Sci. 2007;24(1): 45-57.

177. Schrick B, Hydutsky BW, Blough JL, Mallouk TE. Delivery vehicles for zerovalent metal nanoparticles in soil and groundwater. Chem Mater. 2004;16(11):2187-93.

178. Nie X, Liu J, Zeng X, Yue D. Rapid degradation of hexachlorobenzene by micron $\mathrm{Ag} / \mathrm{Fe}$ bimetal particles. J Environ Sci. 2013;25(3):473-8.
179. Chang C, Lian F, Zhu L. Simultaneous adsorption and degradation of $\gamma-\mathrm{HCH}$ by $\mathrm{nZVI} / \mathrm{Cu}$ bimetallic nanoparticles with activated carbon support. Environ Pollut. 2011;159(10):2507-14.

180. He F, Zhao D. Preparation and characterization of a new class of starch-stabilized bimetallic nanoparticles for degradation of chlorinated hydrocarbons in water. Environ Sci Technol. 2005;39(9): 3314-20.

181. He F, Zhao D, Paul C. Field assessment of carboxymethyl cellulose stabilized iron nanoparticles for in situ destruction of chlorinated solvents in source zones. Water Res. 2009;44:2360-70.

182. O'Hena S, Krug T, Quinn J, Clausen C, Geiger C. Field and laboratory evaluation of the treatment of DNAPL source zones using emulsified zero-valent iron. Remediation. 2006;6(2):35-56.

183. Saleh N, Kim HJ, Phenrat T, Matyjaszewski K, Tilton RD, Lowry $\mathrm{GV}$. Ionic strength and composition affect the mobility of surfacemodified $\mathrm{FeO}$ nanoparticles in water-saturated sand columns. Environ Sci Technol. 2008;42:3349-55.

184. Kanel SR, Nepal D, Manning B, Choi H. Transport of surfacemodified iron nanoparticle in porous media and application to arsenic(III) remediation. J Nano Res. 2007;9:725-35.

185. Comba S, Sethi R. Stabilization of highly concentrated suspensions of iron nanoparticles using shear-thinning gels of xanthan gum. Water Res. 2009;43:3717-26.

186. Lenka H, Petra J, Zdenek S. Nanoscale zero valent iron coating for subsurface application, in Proceedings of the 4th International Conference. 2012;10:23-25.

187. Bystrzejewski M, Pyrzyńska K, Huczko A, Lange H. Carbonencapsulated magnetic nanoparticles as separable and mobile sorbents of heavy metal ions from aqueous solutions. Carbon. 2009;47(4):1201-4.

188. White BR, Stackhouse BT, Holcombe JA. Magnetic $\gamma$-Fe 2 O 3 nanoparticles coated with poly-1-cysteine for chelation of As (III), $\mathrm{Cu}$ (II), Cd (II), Ni (II), Pb (II) and Zn (II). J Hazard Mater. 2009;161(2):848-53.

189. Gomes HI, Dias-Ferreira C, Ribeiro AB, Pamukcu S. Enhanced transport and transformation of zerovalent nanoiron in clay using direct electric current. Water Air Soil Pollut. 2013;224(12):1-12.

190. Sirk KM, Saleh NB, Phenrat T, Kim HJ, Dufour B, Ok J, et al. Effect of adsorbed polyelectrolytes on nanoscale zero valent iron particle attachment to soil surface models. Environ Sci Technol. 2009;43(10):3803-8.

191. Eglal MM, Ramamurthy AS. Nanofer ZVI: morphology, particle characteristics, kinetics, and applications. J Nanomater. 2014. doi: 10.1155/2014/152824.

192. Pensini E, Sleep BE, Yip CM, O'Carroll D. Forces of interaction between fresh iron particles and iron oxide (magnetite): effect of water chemistry and polymer coatings. Colloids Surf A. 2013;433: 104-10. 